Santa Clara University

Scholar Commons

Accounting

Leavey School of Business

$7-2015$

\title{
Management Earnings Forecasts and Value of Analyst Forecast Revisions
}

Yongtae Kim

Santa Clara University, y1kim@scu.edu

Minsup Song

Follow this and additional works at: http://scholarcommons.scu.edu/accounting

Part of the Accounting Commons

\section{Recommended Citation}

Kim, Yongtae, and Minsup Song. "Management Earnings Forecasts and Value of Analyst Forecast Revisions." Management Science 61.7 (2015): 1663-683.

This is the authored accepted version. Published version can be found here - http://dx.doi.org/10.1287/mnsc.2014.1920.

This Article is brought to you for free and open access by the Leavey School of Business at Scholar Commons. It has been accepted for inclusion in Accounting by an authorized administrator of Scholar Commons. For more information, please contact rscroggin@scu.edu. 


\title{
Management Earnings Forecasts and Value of Analyst Forecast Revisions
}

\author{
Yongtae Kim* \\ Leavey School of Business \\ Santa Clara University \\ Santa Clara, CA 95053, USA \\ y1kim@scu.edu \\ Minsup Song \\ Sogang Business School \\ Sogang University \\ Seoul, 121-742, Republic of Korea \\ msong@sogang.ac.kr
}

Management Science, Forthcoming

\begin{abstract}
This study examines the stock-price reactions to analyst forecast revisions around earnings announcements to test whether pre-announcement forecasts reflect analysts' private information or piggybacking on confounding events and news. We find that management earnings forecasts influence the timing and precision of analyst forecasts. More importantly, evidence suggests that prior studies' finding of weaker (stronger) stock-price responses to forecast revisions in the period immediately after (before) the prior-quarter earnings announcement disappears once management earnings forecasts are controlled for. To the extent that management earnings forecasts are public disclosures, our results suggest that the importance of analysts' information discovery role documented in prior studies is likely to be overstated.
\end{abstract}

* Corresponding author: Tel.: (408) 554-4667; Fax: (408) 554-2331

Email: y1kim@scu.edu (Yongtae Kim)

We appreciate the comments and suggestions of Wei Jiang (editor), two anonymous reviewers, an anonymous associate editor, Michael Eames, and workshop participants at the 2013 European Financial Management Association Meeting. 


\section{Management Earnings Forecasts and Value of Analyst Forecast Revisions}

\section{Introduction}

Recent studies show that analysts piggyback their recommendations (Altınkılıç and Hansen 2009, Loh and Stulz 2011) and earnings forecasts (Altınkılıç et al. 2013) on recent news and events, and this ignites a debate over analysts' behavior: Do analysts often provide new information with their reports, or do they instead usually piggyback their reports on recent public information, providing little new information? The growing evidence on piggybacking, however, does not include the important case of analyst forecasts around earnings announcements, which requires further examination, because previous studies credit strong pre-announcement stock-price reactions to significant new information from analysts. This study examines the stock-price reactions to analyst forecast revisions around earnings announcements to test whether pre-announcement forecasts reflect analysts' private information or piggybacking on confounding events and news.

Prior studies suggest that analysts add value through either the discovery of private information and/or their superior ability to produce information by processing public information (Francis et al. 2002, Ivković and Jegadeesh 2004, Frankel et al. 2006, Chen et al. 2010). These studies posit that analyst forecast revisions after an earnings announcement are more likely to reflect analysts' ability to process earnings news and that revisions before the earnings announcement are more likely to capture analysts' discovery of new private information. One study that is closely related to our inquiry is Ivković and Jegadeesh (2004). Ivković and Jegadeesh (2004) find that stock-price reactions to revisions are weakest in the first few weeks after priorquarter earnings announcements and stronger in the week before current-quarter earnings announcements. ${ }^{1}$ They conclude that the value of analyst forecasts stems primarily from analysts' ability to collect and process private information, consistent with the so-called "informed analyst hypothesis." Ivković and Jegadeesh (2004), however, neither control for the confounding effect of public disclosures nor consider analysts'

\footnotetext{
${ }^{1}$ In contrast, findings in Francis et al. (2002) and Frankel et al. (2006) are consistent with the role of processing public information as a dominant source of value in analysts' research. Francis et al. (2002), for example, find a positive association between the market reaction to earnings announcements and the market reaction to analysts' research reports, suggesting that analyst research and earnings announcements are complements of each other.
} 
piggybacking behavior. Analysts' piggybacking on public disclosures may explain patterns of return reactions to analyst forecast revisions.

Recent studies suggest that analysts piggyback their reports on recent public information (Altınkılıç and Hansen 2009, Altınkılıç et al. 2013), implying that analyst forecasts could be linked to news and events that confound stock-price reactions to analyst forecasts. Altınkılıç and Hansen (2009) report evidence that average recommendation revisions do not produce an economically meaningful market reaction after removing recommendations that piggyback on firm news, such as earnings announcements and management forecasts. Loh and Stulz (2011) find that only 12\% of recommendation changes and 5\% of earnings forecast revisions are influential and have a visible stock-price impact. Altınkılıç et al. (2013) show that nearly all analyst forecast revisions follow significant public information events and that forecast announcements have little information when there is no public information event. All three studies note that management forecast is an important information event that could confound return reactions to analyst reports.

While both management forecasts and analyst forecasts are motivated by a desire to align investor expectations with the information they possess, analysts rely heavily on management forecasts in forming their expectations. Prior studies show that management forecasts influence analyst forecasts (e.g., Baginski and Hassell 1990, Cotter et al. 2006) and stock prices (Patell 1976, Penman 1980, Pownall et al. 1993). Management earnings forecasts, especially those issued just before earnings announcements are tantamount to a full revelation of the firm's actual earnings. For analysts who want to be accurate in their forecasts, prompt piggybacking of forecasts on earnings and guidance announcements is essential and easy. Earlier studies (e.g., Patell 1976, Jennings 1987) find that analysts update their forecasts in response to management forecasts. Evidence in Cotter et al. (2006) suggests that approximately 60 percent of analysts revise their forecasts within five days of management forecasts. Therefore, the temporal pattern of management forecasts can affect the temporal pattern of analyst forecast revisions, as well as the value that investors attach to forecast revisions across the event time. ${ }^{2}$

\footnotetext{
${ }^{2}$ Livnat and Zhang (2012) find that market reactions to forecast revisions issued promptly (within three trading days) after corporate disclosures, such as 10-K, 10-Q, and 8-K filings, are greater than reactions to non-prompt revisions. They conclude that investors place more value on analysts' ability to interpret public disclosures.
} 
This study introduces new and unique tests of the "informed analyst hypothesis" and the "piggybacking hypothesis," which are now central in the debate over analysts' economic roles. The tests focus on piggybacking behavior around corporate announcements of earnings and management forecasts. Drawing on the empirical design and the statistics introduced by Ivković and Jegadeesh (2004), we examine whether management forecasts are associated with the timing, relative accuracy, and price impact of analyst forecast revisions. Specifically, we partition the sample revisions into two subsamples: revisions for firms that issue management forecasts and those for firms that do not issue management forecasts during the quarter. We then compare the revision timing, relative forecast accuracy, and stockprice responses to analyst forecast revisions between the two subsamples.

We first document that management forecasts and analyst forecast revisions during the quarter have very similar temporal patterns, which is consistent with analysts updating forecasts in response to management forecasts (e.g., Patell 1976, Jennings 1987). Interestingly, for firms issuing management forecasts, the temporal pattern of relative forecast accuracy and that of management forecasts are remarkably similar. Specifically, relative forecast accuracy is greater (i.e., revised analyst forecasts are more accurate relative to the existing consensus forecast) in weeks during which firms issue management forecasts more frequently. Relative forecast accuracy is also greater for firms with management forecasts than for firms without such forecasts, suggesting that analysts piggyback their revisions on management forecasts.

More importantly, we find that the evidence of weaker (stronger) price reactions to forecast revisions issued immediately after (before) the earnings announcement holds only for the sample of firms that issue management forecasts. For firms without management forecasts, we find no statistical difference between stock-price reactions to revisions in the post-announcement period and those in the pre-announcement period. In addition, stock-price responses to forecast revisions are greater for firms with management forecasts than for firms without management forecasts in the pre-announcement period, while the opposite holds in the post-

\footnotetext{
Although we agree that ignoring other significant public corporate disclosures could result in erroneous conclusions, we note difficulties in disentangling the information content of the forecast revision from that of the firm disclosure itself. The stronger market reaction to prompt revisions may just reflect responses to the disclosures.
} 
announcement period. The temporal pattern of management forecasts seems to be related to these differences in the temporal pattern of the information content between firms with and without management forecasts.

We also directly control for news from management forecasts issued immediately before or concurrently with analyst forecast revisions. We show that weaker (stronger) price reactions to forecast revisions issued immediately after (before) the earnings announcement disappear once we control for management forecast news in the regression. Given that a management forecast is a public disclosure, this evidence casts doubt on the information role of analysts. Rather, the evidence is consistent with analysts piggybacking on recent information events.

The sample period is also partitioned into pre- and post-Regulation Fair Disclosure (Reg FD) periods. Reg FD changes the way that firms communicate with financial analysts and hence changes analysts' information environment. Prior studies (e.g., Irani and Karamanou 2003, Agrawal et al. 2006, Janakiraman et al. 2007, Hahn and Song 2013) document a decrease in analyst following, forecast accuracy, and first-forecast horizon, as well as an increase in analyst forecast dispersion following Reg FD. Kross and Suk (2012) show that Reg FD also influences the interplay between management forecasts and analyst forecast revisions. Because these changes could affect the value of analyst forecast revisions at different points during the event time, the timing and information content of analyst forecast revisions in pre- and post-Reg FD periods are examined separately. Our results are robust in both pre and post-FD periods. In addition, management forecasts are more concentrated in the earnings announcement period during the post-Reg FD period, while most management forecasts are issued later in the quarter during the pre-Reg FD period. This shift in the temporal pattern around Reg FD is also apparent in analyst forecast revisions, providing additional support for the piggybacking hypothesis.

Sample-selection bias is a potential issue for our analyses. That is, firms that issue management forecasts might be fundamentally different from firms that do not issue management forecasts, and our results might be driven by a specific cut of data. We address this sample-selection issue in three different ways. First, we use the propensity score matching strategy. For each firm that issues management forecasts, we select a firm that does not issue management forecasts but has a similar propensity for issuing such forecasts. We then examine market 
reactions to analyst forecast revisions across the event time, using firms that issue management forecasts and their matching firms that do not issue management forecasts. Second, we exclude "quiet" firms (i.e., firms that do not issue management forecasts during four preceding quarters) from the sample and examine price reactions to analyst forecast revisions. Third, we estimate the return sensitivity regressions only with firms that issue management forecasts. Our results are robust across all specifications and samples.

Our study makes several contributions to the literature. First, this study contributes to the debate over the information role of security analysts. When piggybacking is controlled, the evidence shows that the previously documented temporal differences in price reactions to analyst forecast revisions disappear. This evidence is in line with findings from recent studies suggesting that analysts release little new information in their reports (Altınkılıç and Hansen 2009; Loh and Stulz 2011; Altınkılıç et al. 2013). Thus, our study expands the growing evidence of piggybacking (Altınkılıç and Hansen 2009, Altınkılıç et al. 2013).

Second, this study sheds light on assessing the sources of value that analysts bring to the market. Although numerous studies find that analyst forecast revisions are price informative (e.g., Griffin 1976, Givoly and Lakonishok 1979, Givoly and Lakonishok 1980, Elton et al. 1981, Imhoff and Lobo 1984), there is contradicting empirical evidence on the relative importance of two different roles of analysts' research: public information processing and information discovery (Francis et al. 2002; Ivković and Jegadeesh 2004; Frankel et al. 2006; Chen et al. 2010). Our study complements Livnat and Zhang (2012), which also examines the influence of firm disclosures in assessing analysts' roles in processing public information and discovering private information. While Livnat and Zhang's (2012) results are not free from the confounding effects of market reactions to disclosure itself, both studies find that the relative importance of analysts' information discovery role documented in prior studies is likely to be overstated.

Our study also contributes to the literature on the economic consequences of management forecasts. Earlier studies find that analysts update their forecasts in response to management forecasts and that analyst forecasts become more accurate after management forecasts (Waymire 1986, Jennings 1987, Cotter et al. 2006). This study finds broader influences of management forecasts on the characteristics of analyst forecasts. The results suggest that some analysts piggyback their forecasts on guidance news just 
as some do on earnings news. Consequently, the temporal pattern of piggybacking forecasts on earnings reports is broadened to encompass piggybacking forecasts on substantively similar guidance reports. The piggybacking clearly shows analysts' use of recent earnings related news, which improves forecast accuracy.

The paper's results suggest that analysts' information role is less relevant than previously believed and thus support the lack of evidence of new information from analysts. We caution, however, that our study does not suggest that analysts do not add value. Analysts have other important economic roles, such as raising investor awareness and monitoring managerial performance (Bhushan 1989, Hayes 1998, Altınkılıç and Hansen 2000, Irvine et al. 2007).

\section{Research Design}

This paper employs much of the very useful methodology introduced by Ivković and Jegadeesh (2004), drawing on their experimental design and the construction of statistics needed to assess the impact of forecast revisions. We augment their research design with the incidence and timing of management forecasts of quarterly earnings to understand analysts' piggybacking behavior around corporate announcements of earnings and management forecasts and its effect on stock-price reactions around analyst forecast revisions.

\subsection{Sample Selection}

We obtain data on sell-side analyst forecasts of earnings per share (EPS) from the Institutional Brokers' Estimate System (I/B/E/S) detail tape and management forecasts of quarterly earnings from the Company Issued Guidelines (CIG) of Thomson Financial's First Call Historical Database (FCHD) for the period between January 1996 and December 2009. ${ }^{3}$ We begin our sample period in 1996, because the passage of the Private Securities Litigation Reform Act of 1995 expanded safe-harbor protection to firms issuing forward-looking information and thus changed firms' legal environment and incentives for issuing

\footnotetext{
${ }^{3}$ We acknowledge that the CIG database is incomplete and management earnings forecasts of a group of firms might not be included (Houston et al. 2010, Chuk et al. 2013). Misclassifying firms with management earnings forecasts as those without management earnings forecasts, however, will work against finding any difference between these two groups of firms.
} 
management forecasts. We focus on quarterly EPS forecasts that were revised after the prior-quarter $(q-1)$ earnings announcement date. Since we examine analysts' quarterly EPS forecasts, we focus on one-quarterahead management forecasts of quarterly earnings. We obtain earnings announcement dates and financial data from the COMPUSTAT quarterly files and stock-return data from the Center for Research in Security Prices (CRSP) database.

Panel A of Table 1 summarizes the sample-selection process. We use analyst forecast revisions that are issued within 32 trading days after prior quarter earnings announcements and within 30 trading days before current earnings announcements. Sixty-two trading days between two consecutive earnings announcements usually span the entire quarter. To avoid the influence of changes in fiscal quarters or unusual delays in earnings announcements, we exclude forecast revisions issued between two consecutive earnings announcement dates that are less than 30 trading days or more than 100 trading days apart. We also exclude revisions later than 32 trading days after the prior-quarter earnings announcement and earlier than 30 trading days before the current-quarter earnings announcement if there are more than 62 trading days between two consecutive earnings announcements. ${ }^{4}$ After eliminating forecast revisions for which stock returns around revisions are not available, we have 882,987 revisions. We drop revisions of which the absolute value of the forecast revision (changes in forecasts deflated by the last forecast before the revision) is greater than $50 \%$, leaving 755,388 revisions. To avoid the effect of extreme values, we eliminate revisions with extreme price responses to revisions (top and bottom $0.05 \%$ of the distribution of price reactions). We also eliminate revisions with extreme values of individual and consensus forecast error, defined as greater than $100 \%$ of actual earnings. After we eliminate revisions of which control variables are not available, our final sample includes 670,879 revisions, of which 211,928 are upward revisions and 284,812 are downward revisions. ${ }^{5}$ The number of observations for which relative forecast accuracy is calculated (496,740 revisions) is smaller due to "day 0 exclusion" explained in section 2.3. The number of observations used for the regression analyses (384,786 revisions) is smaller, because we exclude forecast revisions made on the priorquarter earnings announcement date and on the day following the announcement.

\footnotetext{
${ }^{4}$ Including these forecast revisions does not change the results in any material manner.

${ }^{5} \mathrm{We}$ exclude the reiterating revisions of which the revised forecast is the same as the prior forecast.
} 
Panel B of Table 1 shows the distribution of the sample by year. Both the number of revisions and the average number of analysts following the firm increase over time. The distribution of the sample by FamaFrench 49 industry classification (untabulated) show that the most represented industry in terms of the number of revisions is Petroleum and Natural Gas, followed by Retail and Banking. In terms of the number of firms in the sample, Banking is the most represented industry, followed by Computer Software and Retail.

\subsection{Timing of Forecast Revisions}

We measure the timing of analyst forecast revisions relative to quarter $q-1$ and quarter $q$ earnings announcement dates. For each individual analyst revision of the one-quarter-ahead earnings forecast, we determine the number of trading days between the revision date and the earnings announcement date. For revisions made after the mid-point of the quarter, we measure revision timing relative to the currentquarter $(q)$ earnings announcement (trading days -30 through -1), and for revisions made at or prior to the mid-point of the quarter, we measure revision timing relative to the prior-quarter $(q-1)$ earnings announcement (trading days 0 through 32 ). These trading days usually span the entire quarter. We then group the forecast revisions into the five periods based on timing. Figure 1 depicts the time line that shows five time periods and time indicator variable construction. We measure the timing of management forecasts based on the same five periods. We compare the temporal patterns of management forecasts and analyst forecast revisions at various points in the event time based on five periods defined in Figure 1.

\subsection{Relative Forecast Accuracy}

We calculate the relative forecast accuracy, $R F A$, as the absolute value of forecast error of the newly released one-quarter-ahead earnings forecast minus the absolute value of forecast error of the consensus forecast one day before the forecast revision, multiplied by $-1 .{ }^{6}$ The consensus forecast summarizes the information available to all analysts prior to the forecast revision, whereas the new forecast conveys the incremental information upon which the analyst revises her/his forecast. A positive (negative) value of $R F A$ indicates that the analyst's revised forecast is more (less) accurate than the consensus forecast. To compute the consensus forecast, we require at least one analyst forecast issued prior to an analyst's

\footnotetext{
${ }^{6}$ Note that our RFA is the relative forecast error in Ivković and Jegadeesh (2004) multiplied by negative one. Forecast accuracy is the inverse of forecast error, which is the absolute value of the difference between forecasted earnings and actual earnings. The smaller the forecast error, the greater is the forecast accuracy.
} 
forecast revision. Under this definition, $R F A$ is undefined on the earnings announcement date, because we cannot compute the consensus forecast for event day 0 , where day 0 is the date of the quarter $q-1$ earnings announcement (“day 0 exclusion," hereafter).

We compare relative forecast accuracy between firms with management forecasts and those without management forecasts for each window of the five forecast periods defined in Figure 1. We also employ the following regression model to examine the temporal pattern of relative forecast accuracy:

$$
\begin{aligned}
& R F A=\beta 1 * \text { DPeriod }-2+\beta_{2} * \text { DPeriod }-1+\beta_{3} * \text { DPeriod } 1+\beta_{4} * \text { DPeriod } 2+\beta_{6} * \text { SIZE } \\
& \quad+\beta_{7} * \text { BM }+\beta_{8} * \text { COVERAGE }+\beta_{9} * \text { SPECIAL }+\beta_{10} * \text { LOSS }+\beta_{11} * \text { DIFFICULTY }+e
\end{aligned}
$$

All variable are defined in the Appendix. We exclude revisions in Period 0 (days $(0,1)$ ) from the multivariate regressions due to "day 0 exclusion" and because the consensus forecast on day 1 exists only when at least one analyst issues forecast on day 0. Doing so is also consistent with our approach in the stock-price response analysis where we exclude such revisions to avoid the confounding effects of market reactions to earnings announcements. We control for the information environment that may affect analyst forecast accuracy. Following the prior literature, we control for firm size (Mikhail et al. 1997, Clement and Tse 2005), book-to-market ratio, and number of analysts following the firm (Stickel 1989). Inclusion of the number of analysts following the firm also controls for competition among analysts (Abarbanell et al. 1995). Earnings characteristics may also affect analysts' forecast timing following earnings announcements (Stickel 1989, Zhang 2008). To control for earnings characteristics, we include analyst forecast errors for prior quarter earnings (Zhang 2008), an indicator for negative earnings (Hayn 1995), and special items in earnings (Bradshaw and Sloan 2002). We estimate equation (1) for the sample revisions for firms with and without management forecasts and compare the coefficients on DPeriod-2-DPeriod 2 between the two groups.

\subsection{Stock-Price Responses to Forecast Revisions}

To examine whether management forecasts affect the return sensitivity to forecast revisions over the event time, we regress stock-price responses on forecast revisions interacted with event-time indicators for the subsample of revisions for firms with and without management forecasts. The 
regression model uses revision timing in three periods: D1 (days $(7,32)$ and days $(-30,-6)), D 2$ (days $(-5$, $-1)$ ), and D3 (days $(2,6)$ ) (See Figure 1 for construction of time indicator variables). D1 corresponds to Periods -2 and 2, D2 corresponds to Period -1, and D3 corresponds to Period 1.

$$
\begin{aligned}
R_{t, t+2} & =\alpha_{0}+\alpha_{1} * F R * D 1+\alpha_{2}^{*} F R * D 2+\alpha_{3}^{*} F R * D 3+\alpha_{4}^{*} \text { SIZE }+\alpha_{5}^{*} B M \\
& +\alpha_{6} * \text { COVERAGE }+\alpha_{7} * \text { SPECIAL }+\alpha_{8} * L O S S+\alpha_{9} * D I F F I C U L T Y+\eta
\end{aligned}
$$

The three event-time indicator variables, $D 2, D 3$, and $D 1$, split the event time into three periods as the pre-, post-, and non-announcement periods, respectively. We exclude the event days $(0,1)$ because price reactions on these days include price reactions to the information contained in prior-quarter earnings announcements. We control for firms' information environment and earnings characteristics. Excluding these control variables does not affect our results in any material way. Under the piggybacking hypothesis, forecast revisions in the period immediately prior to the current-quarter earnings announcements have greater price impacts than those in the period immediately prior to the current quarter earnings $\left(\alpha_{2}>\alpha_{3}\right)$ only in the sample of firms that issue management forecasts.

\subsection{Pre- and Post-Reg FD Periods}

We also examine the timing and information content of analyst forecast revisions in pre- and post-Reg FD periods separately. Reg FD, which became effective on October 23, 2000, has changed the way that firms communicate with financial analysts and other market participants. Reg FD is intended to level the playing field and prohibits selective disclosure of material information to a subset of market participants, such as analysts and institutional investors, without simultaneously disclosing the same information to the investing public. For example, an advance warning about earnings telephoned to a security analyst must also be immediately released to the public. Following implementation of Reg FD, analysts no longer have access to manager's private information before that information becomes public.

Prior studies show that Reg FD leads to changes in analysts' information environment. Irani and Karamanou (2003) find a decrease in analyst following after the passage of Reg FD. Agrawal et al. (2006) find that individual and consensus forecasts become less accurate post-Reg FD, particularly for early forecasts and for smaller companies. Irani and Karamanou (2003), Agrawal et al. (2006), and Hahn and Song (2013) also find an increase in forecast dispersion following Reg FD. Janakiraman et al. (2007) 
suggest that the timing advantage of favored analysts decrease after Reg FD. Specifically, they show that the first forecast horizon of favored analysts decrease more after Reg FD than that of other analysts. Changes in analysts' information environment can potentially alter the relative precision of analysts' information across event time and the value that the market attaches to revisions.

More importantly, Kross and Suk (2012) show that Reg FD influences the interplay between management forecasts and analyst forecast revisions. Specifically, they find that the speed and frequency of individual analysts' forecast revisions following public disclosures such as management forecasts increase dramatically after Reg FD. We define the sample period between 1996 and 2000 as the pre-Reg FD period and that between 2001 and 2009 as the post-Reg FD period. ${ }^{7}$

\section{Empirical Results}

\subsection{Timing of Management Forecasts and Analyst Forecast Revisions}

Panel A of Table 2 reports the frequency of management forecasts over the event time. More than $55 \%$ of management forecasts are issued on the prior-quarter earnings announcement date. Overall, about $57 \%$ of management forecasts are issued during the announcement period of quarter $q-1$ earnings (Period $0){ }^{8}$ Outside Period 0, Period -2 is the period in which most management forecasts are issued (about 30\%), followed by Period 2 (about 10\%).

The temporal pattern of the issuance of management forecasts drastically changes around Reg FD. During the pre-Reg FD period, less than 12\% (14\%) of management forecasts are issued at the time of the quarter $q-1$ earnings announcement (during the announcement period, Period 0 ). The majority of management forecasts (almost 62\%) are issued in Period -2. In contrast, during the post-Reg FD period, about $63 \%(64 \%)$ of management forecasts are issued at the time of the prior-quarter earnings

\footnotetext{
${ }^{7}$ Reg FD becomes effective in October 2000. Our results are qualitatively the same even if we exclude year 2000 from the pre-FD period to avoid the transition effect.

${ }^{8}$ Although these prompt forecast revisions may provide valuable insights with respect to the analysts' role in interpreting public information (Zhang 2008; Livnat ad Zhang 2012), they are less useful in our setting because it is virtually impossible to disentangle market reactions to forecast revisions from market reactions to prior-quarter earnings announcement itself.
} 
announcement (during Period 0). Only about 25\% are issued in Period -2 . This dramatic shift might be attributable to changes in disclosure practices after Reg FD.

Panel B of Table 2 reports the frequency of analyst forecast revisions over the event time. Timing of analyst forecast revisions are more dispersed than that of management forecasts but follow a similar temporal pattern. The shift in the temporal pattern around Reg FD for forecast revisions is also similar to the shift for management forecasts. This change in the temporal pattern of analyst forecast revisions around Reg FD seems to be more pronounced for firms that issue management forecasts than for firms without management forecasts.

\subsection{Timing of Forecast Revisions and Relative Forecast Accuracy}

Table 3 reports relative forecast accuracy over five forecast periods. Forecast revisions in Period 0 include only forecast revisions on day (1) due to "day 0 exclusion." For the full sample of forecast revisions, relative forecast accuracy in the pre-announcement period (Periods -2 and -1 ) is greater than those in the postannouncement period (Periods 1 and 2). Relative forecast accuracy in Period -1 is lower than those in Period -2 . We observe a similar temporal pattern of relative forecast accuracy in the pre- and post-Reg FD periods. The improvement in analyst forecast accuracy over time is more significant in the pre-Reg FD period than in the postReg FD period, however, suggesting that the disappearance of implicit guidance after Reg FD might have decreased analysts' information advantage later in the quarter (Janakiraman et al. 2007). ${ }^{9}$

We also compare relative forecast accuracy between sample revisions for firms with management forecasts and those for firms without management forecasts. Relative forecast accuracy is greater for firms with management forecasts than those for firms without such forecasts. Greater improvement in forecast accuracy through the forecast revision for firms with management forecasts relative to those for firms without such forecasts are observed both in the pre- and post-Reg FD periods. This evidence suggests that analysts piggyback their forecasts on management forecasts.

Table 4 reports results from the regression analysis. Because the residuals may be correlated across analysts and/or over time, we report test statistics and significance levels for all regressions based on standard errors adjusted by a two-dimensional cluster at the analyst and quarter levels (Petersen 2008, Gow et al. 2010).

\footnotetext{
${ }^{9}$ Lower relative forecast accuracy in the post-Reg FD period are consistent with a decrease in analysts' forecast quality after Reg FD (Agrawal et al. 2006).
} 
The results including revisions in Period 0 (actually revisions on day (1) due to "day 0 exclusion") are qualitatively the same as those tabulated in Table $4 .{ }^{10}$

As shown in Table 4, consistent with results in Table 3, relative forecast accuracy in Period -2 is greatest, followed by those in Period -1 , and then Period 2. We also compare relative forecast accuracy in different periods between firms with and without management forecasts. Again, consistent with results in Table 3, improvement in analyst forecast accuracy through the forecast revision is greater (i.e., greater coefficients on DPeriod -2, DPeriod -1, DPeriod 1, and DPeriod 2) for firms with management forecasts than for firms without management forecasts. Differences in coefficients are statistically significant at the one-percent level. Similar patterns are observed in both the pre- and post-Reg FD periods (untabulated). Improvement in analyst forecast accuracy through revisions is greater in the pre-announcement period than in the post-announcement period, and improvement in forecast accuracy is more pronounced for firms that issue management forecasts.

To further understand the relation between management forecasts and the temporal pattern of relative forecast accuracy, we graph the frequency of management forecasts and the mean relative forecast accuracy for firms with and without management forecasts over the event time. In Figure 2, event time is expressed as the number of weeks from the prior-quarter earnings announcement or the current-quarter earnings announcement.

As shown in Figure 2, the temporal pattern of relative forecast accuracy for firms that issue management forecasts is remarkably similar to the temporal pattern of the frequency of management forecasts. Specifically, relative forecast accuracy is higher in the period during which management forecasts are more frequently issued. For firms that do not issue management forecasts, the temporal pattern of relative forecast accuracy is not as apparent as for firms with management forecasts. The similarity in the temporal pattern of relative forecast accuracy and the frequency of management forecasts

\footnotetext{
${ }^{10}$ We estimate forecast-accuracy regressions and price-reaction regressions for firms with and without management earnings forecasts separately, because we need to compare coefficients not only between two subsamples but also across different periods for each subsample. The results from the pooled regressions with an indicator variable for the revisions with management earnings forecasts, along with interactions of the indicator variable and other variables, are qualitatively similar to those reported in Tables 4 and 5.
} 
over the event time is even more pronounced in the post-Reg FD period, potentially because revisions in the pre-Reg FD period are influenced not only by management forecasts but also by implicit and selective management guidance of quarterly earnings. This evidence is consistent with Kross and Suk (2012) who find increases in analysts' use of public information such as management forecasts after Reg FD.

\subsection{Price Reactions to Forecast Revisions}

In this section, we examine whether the information content of analyst forecast revisions at various points in the event time differs depending on whether or not firms issue management forecasts. Under the piggybacking hypothesis, stock-price responses between pre- and post-announcement periods are expected to differ only in the sample of firms that issue management forecasts, but not in the sample of firms without such forecasts.

We estimate regression equation (2) and report the results for the entire sample period (1996-2009) in Panel A of Table 5. Again, we report test statistics and significance levels for all regressions based on standard errors adjusted by a two-dimensional cluster at the analyst and quarter levels. In Panel A, for the full sample of forecast revisions, the coefficient on $F R^{*} D 3$ is smaller than the coefficients on $F R^{*} D 1$ and $F R^{*} D 2$. When we partition the sample into forecast revisions for firms with and without management forecasts, however, the full sample results hold only for the sample of firms that issue management forecasts. For firms that do not issue management forecasts, the coefficient on $F R * D 2$ and the coefficient on $F R * D 3$ are not statistically different $(\mathrm{t}$-value $=0.58)$, suggesting that the price impact of analyst forecast revisions in the post-announcement period is comparable to that of revisions in the pre-announcement period. The stock-price reaction to revisions is the strongest in D1. In Table 2, we show that management forecasts are most frequent in Periods -2 and 2, which corresponds to D1 in Table 5. Thus, the strongest market reaction to revisions in this period might actually be the reaction to management forecasts, not analyst forecast revisions.

We also find that stock-price responses to forecast revisions are greater for firms with management forecasts than for firms without management forecasts during the non-announcement period $(D 1)$ and in the period immediately before the current-quarter earnings announcement $(D 2)$, while the opposite holds in the 
period immediately following the prior-quarter earnings announcement (D3). Because management forecasts are most frequent in Period -2, as shown in Table 2, and because analysts tend to revise forecasts over several days subsequent to management forecasts (Cotter et al. 2006), it appears that the temporal pattern of management forecasts affect the different temporal patterns of the information content of revisions between firms with and without management forecasts. This evidence is consistent with analysts piggybacking their reports on recent management forecasts. If analysts piggyback their reports on recent public news, then abnormal returns around analyst forecast revisions will show the arrival of early news. Figure 3 shows the median of the absolute value of abnormal returns over days -5 to 3 around analyst forecast revisions with and without management forecasts. The graph shows that stock-price reactions start on days -2 and -1 for firms that issue management forecasts, suggesting an early arrival of news. This phenomenon is less pronounced for analyst forecast revisions for firms without management forecasts.

Panel B of Table 5 reports the regression results for pre- and post- Reg FD periods. Again, for both preand post-Reg FD subperiods, weaker (stronger) stock-price responses to forecast revisions in the postannouncement (pre-announcement) period holds only in the sample of revisions for firms that issue management forecasts. In the sample of revisions for firms that do not issue management forecasts, the difference in the coefficient on $F R^{*} D 2$ and that on $F R^{*} D 3$ is statistically insignificant. Thus, it appears that the temporal difference in the price impact of forecast revisions is driven by the temporal pattern of management forecasts.

We also estimate regressions for upward and downward revisions separately and summarize the results in Table 6. For upward forecast revisions, Ivković and Jegadeesh (2004) find that the coefficient on $F R^{*} D 2$ is greatest, followed by the coefficient on $F R^{*} D 1$. They find that the coefficient on $F R^{*} D 3$ is negative. We find that such results hold only for the pre-Reg FD period. For the post-Reg FD period, the difference between the coefficient on $F R^{*} D 1$ and that on $F R^{*} D 2$ is statistically insignificant. For the sample of downward revisions, we find that the coefficient on $F R^{*} D 1$ is the greatest.

More importantly though, the finding that the coefficient on $F R^{*} D 3$ is smaller than that on $F R^{*} D 2$ (i.e., weaker return responses to forecast revisions in the period immediately following the earnings announcement than those in the period immediately prior to the earnings announcement) holds only for 
upward and downward revisions for firms that issue management forecasts. For firms that do not issue management forecasts, stock-price responses to forecast revisions in the week following the prior-quarter earnings announcement are statistically indifferent from those in the week immediately before the currentquarter earnings announcement, except for upward revisions in the pre-Reg FD period. ${ }^{11}$

Next, we directly control for the confounding effect of management forecasts by including management forecast news to the regression equation (5). We identify management forecasts issued between one day prior to and two days after individual analysts' forecast revision and compute management forecast news, $M F$, as management forecast minus mean consensus analyst forecast on the day before the issuance of management forecast, deflated by the absolute value of mean consensus analyst forecast. We assign zero value to $M F$ if there is no management forecast issued prior to analyst forecast revision. We interact $M F$ with the three event-time indicator variables, $D 2, D 3$, and $D 1$, that split the event time into three periods as the pre-, post-, and non-announcement periods, respectively. If management forecast is a confounding factor that explains the temporal pattern of the market reaction to forecast revisions, the difference between the coefficient on $F R^{*} D 2$ and the coefficient on $F R^{*} D 3$ will become insignificant once we control for the effect of management forecast news.

Panel A of Table 7 reports the results. The number of observations in this table is smaller than that in Table 5 as observations with qualitative management forecasts are excluded because $M F$ cannot be calculated for qualitative forecasts. The results with the full sample of analyst forecast revisions show significantly positive price impact of management forecasts issued in pre-announcement (D2) and nonannouncement periods $(D 1)$. More importantly, the difference between the coefficient on $F R^{*} D 2$ and the coefficient on $F R^{*} D 3$ is insignificant after controlling for the effect of management forecast news. We find the similar results for both the pre-FD and post-FD periods. Thus the evidence in Table 7 suggests that the weaker (stronger) price reaction to analyst forecast revisions issued immediately after (before) the earnings announcement is largely attributable to the confounding effect of management forecasts.

\footnotetext{
${ }^{11}$ Selective disclosure to a group of analysts may contribute to a greater price impact of upward revisions in the preannouncement period during the pre-Reg FD period.
} 
In Panel A of Table 7, the analyses include both firms that issue management forecasts and firms that do not. If the two types of firms are fundamentally different, our results could be driven by differences in the two types of firms rather than by the confounding effect of voluntary public disclosures. To mitigate this concern, we confine observations to ones that are subject to issuance of management forecasts and report the results in Panel B of Table 7. Again, observations with qualitative management forecasts are excluded. The coefficient on $F R^{*} D 2$ is statistically insignificant. In addition, the difference between the coefficient on $F R^{*} D 2$ and the coefficient on $F R^{*} D 3$ is insignificant, suggesting that the different return sensitivity to forecast revisions between pre- and post-announcement periods disappears once the confounding effect of management forecasts is controlled for.

We also control for a potential interaction effect of $M F$ and $F R$ by including the set of covariates with interactions $M F^{*} F R^{*} D 1, M F^{*} F R^{*} D 2$, and $M F^{*} F R^{*} D 3$ in the model. We further refine return sensitivity to confirmatory and dissenting analyst forecasts by splitting $M F^{*} F R$ interactions into $\operatorname{Max}\left(M F^{*} F R, 0\right)$ and $\operatorname{Min}\left(0, M F^{*} F R\right)$. Inclusion of interactions and consideration of confirmatory and dissenting analyst forecasts do not change the tenor of the results. These results are also robust to firm fixed effects, as shown in Panel C of Table 7.

\subsection{Sample selection bias}

Sample selection bias is potentially an issue for our analyses, as firms that issue management forecasts might be fundamentally different from firms that do not issue management forecasts. Although analyses in Panels B and C of Table 7 mitigate this concern, we further address the sample selection issue in two additional ways. First, we use the propensity score matching strategy. For each firm that issues management forecasts, we select a firm that does not issue management forecasts but has a similar propensity for issuing management forecasts. ${ }^{12}$ We then examine the market reaction to analyst forecast revisions across the event time using firms that issue management forecasts and their matching firms that

\footnotetext{
${ }^{12}$ Propensity score is estimated by the following logistic regression for each fiscal quarter: $\operatorname{Pr}(M E F=1)=F\left(\alpha_{0}+\alpha_{1}\right.$ $L N_{-} T A+\alpha_{2}$ BIG4 $+\alpha_{3}$ BETA $+\alpha_{4}$ ABSCHGROA $+\alpha_{5}$ STD_AF $+\alpha_{6}$ EARNINGS_VOLATILITY $+\alpha_{7}$ ASSET_GROWTH $+\bar{\alpha}_{8}$ LEVERAGE $+\alpha_{9}$ SEGMENTS $+\alpha_{10}$ ROA $+\alpha_{11}$ LOSS $+\alpha_{12}$ HHI $+\alpha_{13}$ LITIGATION $+\alpha_{14}$ COVERAGE). All variables are defined in the Appendix. For each fiscal quarter, firms with the closest propensity score are matched within caliper width of 0.1 without replacement.
} 
do not issue management forecasts. Table 8 reports the results. The number of observations for the matched guidance firm sample and that for the matched non-guidance firm sample is different because propensity score matching is done at the firm-quarter level, but the analysis is done at the forecast revision level. There could be more than one analyst forecast revision for each firm quarter. The results confirm our earlier findings that the market reaction to analyst forecast revisions is significantly different only for the subsample of firms that issue management forecasts. Moreover, the significant difference in the market reaction to analyst forecast revisions between pre- and post-announcement periods disappears once management forecasts are controlled for.

Second, we exclude "quiet" firms from the sample and re-estimate the return sensitivity regressions. We exclude analyst forecast revisions for firms that do not issue management forecasts for four preceding quarters, because they are generally quiet firms and the information flow for these firms could be minimal and therefore fundamentally different from firms that issue management forecasts. We report the results in Table 9. As shown, the results are qualitatively similar to those reported in Tables 5 and 7. The significant difference in return sensitivity to analyst forecast revisions between pre- and postannouncement periods disappears when management forecasts are controlled for. ${ }^{13}$

\subsection{Timing of Other Information Events and Return Sensitivity to Forecast Revisions}

In addition to earnings announcements and management forecasts, other information events could confound return reactions to analyst forecast revisions. Following Altınkılıç and Hansen (2009), Loh and Stulz (2011), and Altınkılıç et al. (2013), we consider additional information events, including security offerings, multiple analyst recommendations, mergers and acquisitions, and dividend declarations, and examine the effect of such events on return sensitivity to forecast revisions across the event time. We obtain equity offerings and debt offerings from Securities Data Corporation's (SDC) Global New Issue database, multiple analyst recommendations from $\mathrm{I} / \mathrm{B} / \mathrm{E} / \mathrm{S}$, mergers and acquisitions from the SDC mergers and acquisitions database, and data on dividend declarations from CRSP.

\footnotetext{
${ }^{13}$ Inclusion of firm fixed effects, the interaction of analyst forecast revisions and management forecast news, and confirmatory/dissenting analyst forecasts in Tables 8 and 9 do not change the tenor of the results.
} 
Panel A of Table 10 summarizes the timing of information events. Similar to management forecasts and analyst forecast revisions, other information events are frequent during the earnings announcement period (i.e., days 0 and 1 around quarterly earnings announcements). Unlike management forecasts and analyst forecast revisions, however, other information events occur more frequently during Period 2 (i.e., days $(7,32))$ than in Period -2 (i.e., days $(-30,-6)$ ). Considering the lag between information events and analyst forecasts piggybacking on these events, information events in Period -2 could affect market reactions to analyst forecast revisions in Period -2 as well as those in Period -1 (i.e., days $(-5,-1)$ ). Less frequent other information events during Period -2 suggest that analysts are more likely to piggyback on management forecasts than on other information events during the pre-announcement period.

We also examine market reactions to analyst forecast revisions conditional on other information events. We first exclude analyst forecast revisions for firms issuing management forecasts from the sample. We then divide the remaining analyst forecast revisions into revisions with other information events and those without. Panel B of Table 10 reports the results. As shown, the market reaction to analyst forecast revisions is not statistically different between pre- and post-announcement periods for both forecast revisions with and without other information events. The result in Panel B of Table 10 confirms the evidence in earlier tables (i.e., the difference in the market reaction to forecast revisions between pre- and post-announcement periods is significantly different only for forecast revisions with management forecasts) and suggests that other information events play a less significant role than that of management forecasts in determining market reactions to analyst forecast revisions. In Panel C of Table 10, we include management forecasts in information events and test market reactions to analyst forecast revisions with and without all information events. When we include management forecasts in information events, the difference in market reactions to analyst forecast revisions between pre- and post-announcement period becomes significant for forecast revisions with information events. This result is consistent with those in Table 5 and suggests that differential market reactions to analyst forecast revisions between pre- and post-announcement periods can be attributed primarily to the confounding effect of management forecasts. 


\subsection{Market Reactions to Management Forecasts and Other Information Events Conditional on Analyst Forecast Revisions}

Considering that analysts' career paths and wealth are associated with their forecast accuracy (e.g., Mikhail et al. 1999, Altınkılıç et al. 2013), analysts' incentive for piggybacking on management forecasts would be greater in the pre-announcement period, when management forecasts become very accurate. In our sample, the mean value of management forecast error, calculated as management forecast minus actual earnings scaled by the absolute value of actual earnings is 0.0001 in Period -2 and -0.0009 in Period -1 , both of which are insignificantly different from zero, suggesting that management forecasts issued in these periods are very accurate.

While information events can confound return responses to analyst forecast revisions, analyst forecast revisions may also confound return responses to information events. We examine market reactions to management forecasts with or without analyst forecast revisions in the vicinity (i.e., days (-1, +5 ) around management forecasts). Specifically, we regress three-day cumulative abnormal returns on the interaction of management forecast news, $M F$, and the period indicators (i.e., D1, D2, and D3). Untabulated results show that the magnitudes of coefficients on $M F^{*} D 1$ and $M F^{*} D 3$ are larger for firms with analyst forecasts than for those without analyst forecasts. The coefficients on $M F^{*} D 2$, however, are not significantly different between the two subsamples. This evidence suggests that while analyst forecasts may affect market reactions to management forecasts to some degree in the non-announcement and post-announcement periods, the incremental information from analyst forecasts is not significant in the pre-announcement period. Market reactions to management forecasts are strongest during the preannouncement period and weakest during the post-announcement period. The strong market reaction to management forecasts during the pre-announcement period could provide incentives for analysts to piggyback on management forecasts during this period.

We also examine market reactions to other information events with or without analyst forecast revisions in the vicinity (i.e., days $(-1,+5)$ around information events). Unlike in the case of management forecasts, for which we can determine the direction and the magnitude of news by comparing 
management forecasts to existing consensus analyst forecasts, we cannot reliably determine whether such events as equity/debt offerings or mergers and acquisitions deliver good or bad news. Therefore, for other information events, we regress the absolute value of three-day cumulative abnormal returns around other information events on the period indicators (i.e., D1, D2, and D3). Untabulated results show that while market reactions in the non-announcement period are stronger for information events with analyst forecasts in the vicinity than for those without analyst forecasts, market reactions in the preannouncement periods are not different between the two subsamples. Thus, incremental information from analyst forecasts is not significant in the pre-announcement period. Similar to the case of management forecasts, the market reaction is strongest in the pre-announcement period.

\section{Conclusions}

Previous studies credit strong stock-price reactions around analyst forecast revisions immediately before earnings announcement to significant new information from analysts. Ivković and Jegadeesh (2004), for example, find that the precision of the information that analysts provide varies with event time, following patterns consistent with the plausible availability of private and public information, and conclude that the value of analyst forecasts stems primarily from analysts' ability to collect and process private information. They, however, neither control for the confounding effect of public disclosures nor consider analysts' piggybacking behavior. Our study introduces new and unique tests of the "informed analyst hypothesis" and the "piggybacking hypothesis" and offers insights on the role of management information release. We provide evidence suggesting that the temporal difference in the price impact of forecast revisions across the event time is driven largely by the confounding effect of management forecasts.

The temporal pattern of analyst forecast revisions across the event time relative to earnings announcements mimics the temporal pattern of management forecasts. Furthermore, the temporal pattern of relative forecast accuracy and that of management forecasts are remarkably similar. Improvement in analysts' forecast accuracy through revisions is greater for firms that issue management forecasts. More importantly, the evidence of weaker stock-price responses to forecast revisions in the period immediately 
after the prior-quarter earnings announcement holds only for the sample of firms that issue management forecasts. For firms that do not issue management forecasts, stock-price responses to forecast revisions in the week following the prior-quarter earnings announcement are as strong as those in the week immediately before the current-quarter earnings announcement. This result is more pronounced in the post-Reg FD period. We further show that the weaker (stronger) price reaction to forecast revisions issued immediately after (before) the earnings announcement disappears when we control for the effect of management forecasts news. Thus the results suggest that management forecasts affect the price impact of forecast revisions over the event time.

Our results are robust to three different approaches that address the sample selection concern and are consistent across different specifications, which include firm fixed effects, the interaction of analyst forecast revisions and management forecast news, and confirmatory/dissenting analyst forecasts. Overall, evidence suggests that management forecasts are related to the timing as well as the relative accuracy and information content of analyst forecast revisions across the event time. To the extent that management forecasts are public disclosures, our results cast doubt on the "informed analyst hypothesis." Rather, the results are consistent with analysts piggybacking their reports on recent public information events (Altınkılıç and Hansen 2009, Altınkılıç et al. 2013).

Management forecasts are motivated by a desire to align analyst and investor expectations with information that management possesses. While analysts piggyback their forecasts on management forecasts, management's decision to release information is endogenous. That is, managers make voluntary disclosure decisions based on the perceived costs and benefits of such disclosures and the potential impact on analyst expectations. Although a full exploration of the endogenous decision that management makes for information release and its impact on analyst information environment would be interesting, it is beyond the scope of this paper. We leave such an investigation to future research. 


\section{REFERENCES}

Abarbanell JS, Lanen WN, Verrecchia RE (1995) Analysts' forecasts as proxies for investor beliefs in empirical research. J. Accounting Econom. 20(1): 31-60.

Agrawal A, Chadha S, Chen MA (2006) Who is afraid of reg fd? The behavior and performance of sellside analysts following the sec's fair disclosure rules. J. Business 79(6): 2811-2834.

Altınkılıç O, Balashov V, Hansen R (2013) Are analysts' forecasts informative to the general public? Management Sci. 59(11): 2550-2565.

Altınkılıç O, Hansen RS (2009) On the information role of stock recommendation revisions. $J$. Accounting Econom. 48(1): 17-36.

Baginski SP, Hassell JM (1990) The market interpretation of management earnings forecasts as a predictor of subsequent financial analyst forecast revision. Accounting Rev. 65(1): 175-190.

Bradshaw MT, Sloan RG (2002) GAAP versus the street: An empirical assessment of two alternative definitions of earnings. J. Accounting Res. 40(1): 41-66.

Chen X, Cheng Q, Lo K (2010) On the relationship between analyst reports and corporate disclosures: Exploring the roles of information discovery and interpretation. J. Accounting Econom. 49(3): 206-226.

Chuk E, Matsumoto D, Miller GS (2013) Assessing methods of identifying management forecasts: Cig vs. Researcher collected. J. Accounting and Econom. 55(1): 23-42.

Clement MB, Tse SY (2005) Financial analyst characteristics and herding behavior in forecasting. $J$. Finance 60(1): 307-341.

Cotter J, Tuna I, Wysocki PD (2006) Expectations management and beatable targets: How do analysts react to explicit earnings guidance? Cont. Accounting Res. 23(3): 593-624.

Elton EJ, Gruber MJ, Gultekin MN (1981) Expectations and share prices. Management Sci. 27(9): 975987.

Francis J, Schipper K, Vincent L (2002) Earnings announcements and competing information. $J$. Accounting Econom. 33(3): 313-343.

Frankel R, Kothari SP, Weber J (2006) Determinants of the informativeness of analyst research. $J$. Accounting Econom. 41(1/2): 29-54.

Givoly D, Lakonishok J (1979) The information content of financial analysts' forecasts of earnings: Some evidence on semi-strong inefficiency. J. Accounting Econom. 1(3): 165-185.

Givoly D, Lakonishok J (1980) Financial analysts' forecasts of earnings. J. Banking Finance 4(3): 221233.

Gow ID, Ormazabal G, Taylor DJ (2010) Correcting for cross-sectional and time-series dependence in accounting research. Accounting Rev. 85(2): 483-512.

Griffin PA (1976) Competitive information in the stock market: An empirical study of earning, dividends and analysts' forecasts. J. Finance 31(2): 631-650.

Hahn T, Song M (2013) Regulation fair disclosure and analysts' reliance on earnings announcements. $J$. Accounting Pub. Policy 32(1): 26-43.

Hayn C (1995) The information content of losses. J. Accounting Econom. 20(2): 125-153. 
Houston JF, Lev B, Tucker JW (2010) To guide or not to guide? Causes and consequences of stopping quarterly earnings guidance. Cont. Accounting Res. 27(1): 143-185.

Imhoff EA, Lobo GJ (1984) Information content of analysts' composite forecast revisions. J. Accounting Res. 22(2): 541-554.

Irani AJ, Karamanou I (2003) Regulation fair disclosure, analyst following, and analyst forecast dispersion. Accounting Horizons 17(1): 15-29.

Ivković Z, Jegadeesh N (2004) The timing and value of forecast and recommendation revisions. $J$. Financial Econom. 73(3): 433-463.

Janakiraman S, Radhakrishnan S, Szwejkowski R (2007) Regulation fair disclosure and analysts' firstforecast horizon. J. Accounting, Auditing Finance 22(2): 339-378.

Jennings R (1987) Unsystematic security price movements, management earnings forecasts, and revisions in consensus analyst earnings forecasts. J. Accounting Res. 25(1): 90-110.

Kross WJ, Suk I (2012) Does regulation fd work? Evidence from analysts' reliance on public disclosure. J. Accounting Econom. 53(1/2): 225-248.

Livnat J, Zhang Y (2012) Information interpretation or information discovery: Which role of analysts do investors value more? Revi. Accounting Stud. 17(3): 612-641.

Loh RK, Stulz RM (2011) When are analyst recommendation changes influential? R. Financial Stud. 24(2): 593-627.

Mikhail MB, Walther BR, Willis RH (1997) Do security analysts improve their performance with experience? J. Accounting Res. 35(3): 131-157.

Mikhail MB, Walther BR, Willis RH (1999) Does forecast accuracy matter to security analysts? Accounting Rev. 74(2): 185-200.

Patell JM (1976) Corporate forecasts of earnings per share and stock price behavior: Empirical tests. $J$. Accounting Res. 14(2): 246-276.

Penman SH (1980) An empirical investigation of the voluntary disclosure of corporate earnings forecasts. J. Accounting Res. 18(1): 132-160.

Petersen MA (2008) Estimating standard errors in finance panel data sets: Comparing approaches. $R$. Financial Stud. 22(1): 435-480.

Pownall G, Wasley C, Waymire G (1993) The stock price effects of alternative types of management earnings forecasts. Accounting Rev. 68(4): 896-912.

Stickel SE (1989) The timing of and incentives for annual earnings forecasts near interim earnings announcements. J. Accounting Econom. 11(2/3): 275-292.

Waymire G (1986) Additional evidence on the accuracy of analyst forecasts before and after voluntary management earnings forecasts. Accounting Rev. 61(1): 129.

Zhang Y (2008) Analyst responsiveness and the post-earnings-announcement drift. J. Accounting Econom. 46(1): 201-215. 


\section{Appendix Variable definitions}

\begin{tabular}{|c|c|}
\hline Variable name & Definition \\
\hline$A B S C H G R O A$ & $\begin{array}{l}\text { absolute value of the change in ROA (earnings before extraordinary items } \\
\text { scaled by lagged total assets) from quarter } q-4 \text { to quarter } q\end{array}$ \\
\hline ASSET_GROWTH & percentage asset growth from quarter $q-4$ to quarter $q$ \\
\hline BETA & market beta using daily return data estimated over the past one year period \\
\hline BIG4 & $\begin{array}{l}\text { an indicator variable that takes the value of one if one of Big } 4 \text { is the external } \\
\text { auditor, and zero otherwise }\end{array}$ \\
\hline$B M$ & $\begin{array}{l}\text { book value of equity divided by the market value of equity at the end of } \\
\text { quarter } q-1\end{array}$ \\
\hline COVERAGE & $\begin{array}{l}\text { natural logarithm of the number of analysts who issue quarterly EPS forecast } \\
\text { between quarter } q-1 \text { and quarter } q \text { earnings announcement dates }\end{array}$ \\
\hline D1 & $\begin{array}{l}\text { an indicator of non-announcement period which takes the value of one if an } \\
\text { analyst's forecast is issued between days }(-30,-6) \text { or }(7,32) \text {, and zero } \\
\text { otherwise }\end{array}$ \\
\hline D2 & $\begin{array}{l}\text { an indicator of pre-announcement period which takes the value of one if an } \\
\text { analyst's forecast is issued between days }(-5,-1) \text {, and zero otherwise }\end{array}$ \\
\hline D3 & $\begin{array}{l}\text { an indicator of post-announcement period which takes the value of one if an } \\
\text { analyst's forecast is issued between days }(2,6) \text {, and zero otherwise }\end{array}$ \\
\hline DIFFICULTY & analysts' mean consensus forecast error for quarter $q-1$ EPS \\
\hline DPeriod -2 (-1, 1, o & $\begin{array}{l}\text { an indicator variable that takes the value of one if the forecast revision is } \\
\text { issued in Period }-2(-1,1 \text {, or } 2) \text {, and zero otherwise, where Period }-2 \text { includes } \\
\text { days }(-30,-6) \text { relative to quarter } q \text { earnings announcement, Period }-1 \text { includes } \\
\text { days }(-5,-1) \text { relative to quarter } q \text { earnings announcement, Period } 1 \text { includes } \\
\text { days }(2,6) \text { relative to quarter } q-1 \text { earnings announcement, and Period } 2 \\
\text { includes days }(7,32) \text { relative to quarter } q-1 \text { earnings announcement. }\end{array}$ \\
\hline EARNINGS_VOLATILITY & $\begin{array}{l}\text { standard deviation of quarterly ROA over the past seven years (requiring at } \\
\text { least three non-missing observations) }\end{array}$ \\
\hline$F R$ & $\begin{array}{l}\text { individual analyst forecast revision deflated by the absolute value of prior } \\
\text { forecast. Specifically, for every forecast revision made by analyst } i \text { for stock } j \\
\text { on day } t \text {, we define forecast revision } F R \text { as follows: } F R_{i j t}=100 \mathrm{x} \\
{\left[\left(\text { new }_{\text {forecast }} \text { fort }_{i j}-\text { old_forecast }_{i j}\right) / \mathrm{Abs}\left(\text { old_forecast }_{i j}\right)\right] \text { where } n e w \text { forecast }_{i j t}} \\
\text { is the revised forecast on day } t \text { and } \text { old_forecast }_{i j} \text { is the last forecast by the } \\
\text { same analyst before the revision. We truncate } F R \text { at } \pm 50 \% \text {. }\end{array}$ \\
\hline$H H I$ & Hirfindahl index using revenues of all firms in the same four-digit SIC code \\
\hline LEVERAGE & ratio of total liabilities to total assets at the beginning of the quarter \\
\hline LITIGATION & $\begin{array}{l}\text { an indicator variables as of one if SIC code is in }(2833-2836,3570-3577 \text {, } \\
3600-3674,5200-5961 \text {, or } 7370-7374)\end{array}$ \\
\hline$L N \_T A$ & natural logarithm of total assets at the beginning of the quarter \\
\hline$L \overline{O S S}$ & $\begin{array}{l}\text { an indicator variable that takes the value of one if quarter } q-1 \text { EPS is negative, } \\
\text { and zero otherwise }\end{array}$ \\
\hline $\operatorname{Max}\left(M F^{*} F R, 0\right)$ & $\begin{array}{l}\text { equals } M F^{*} F R \text { if management forecast and analyst forecast revisions are both } \\
\text { good news (i.e., both } M F \text { and } F R \text { are positive) or both bad news (i.e., both } M F \\
\text { or } F R \text { are negative), and zero otherwise }\end{array}$ \\
\hline$M E F$ & $\begin{array}{l}\text { an indicator variable that takes the value of one if the firm issues management } \\
\text { forecast during the quarter, and zero otherwise }\end{array}$ \\
\hline $\operatorname{Min}\left(0, M F^{*} F R\right)$ & $\begin{array}{l}\text { equals } M F^{*} F R \text { if management forecast is good (bad) news forecast but } \\
\text { analyst forecast revisions is bad (good) news forecast revision, and zero } \\
\text { otherwise }\end{array}$ \\
\hline
\end{tabular}




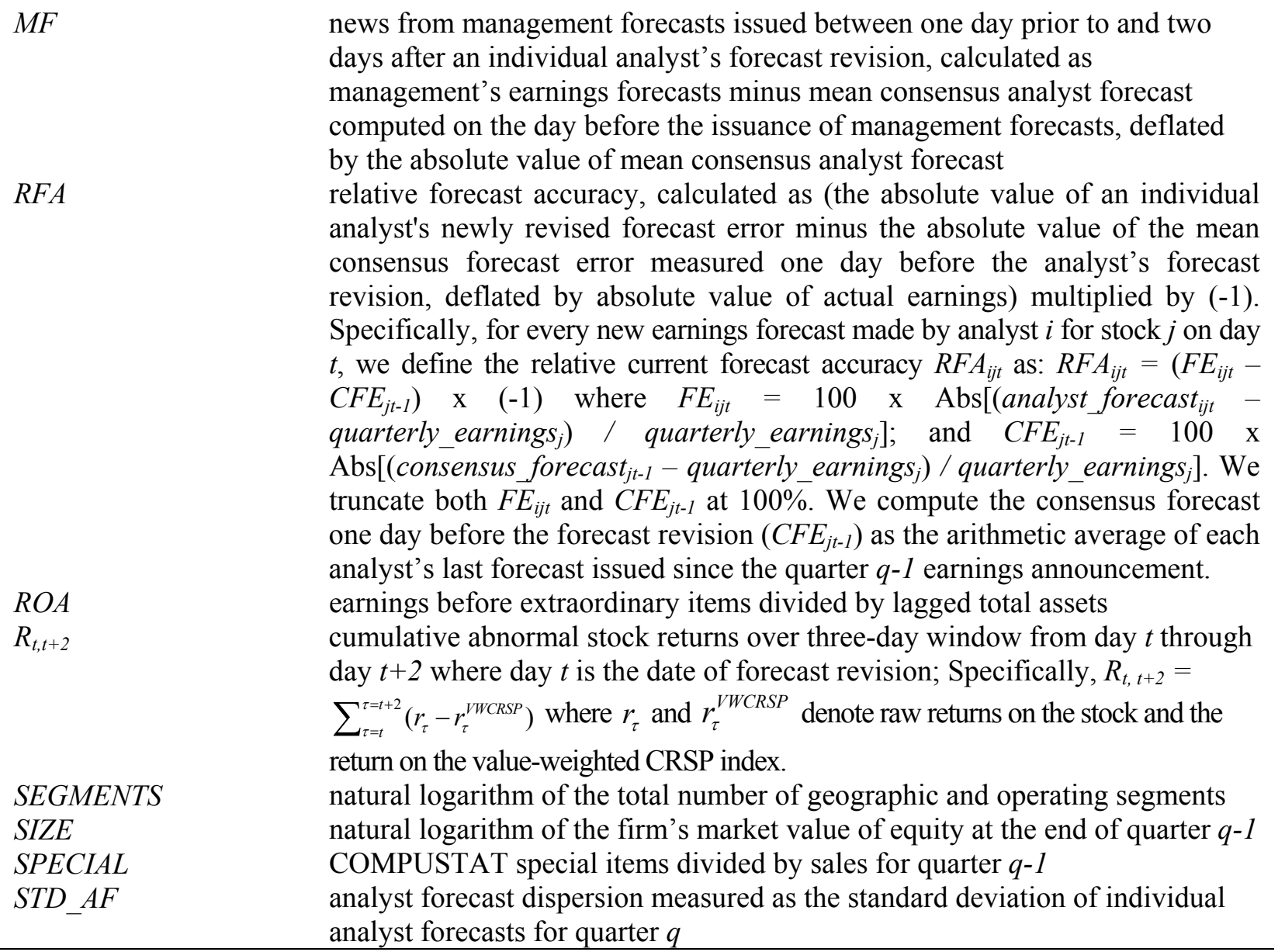




\section{Figure 1}

\section{Timeline}

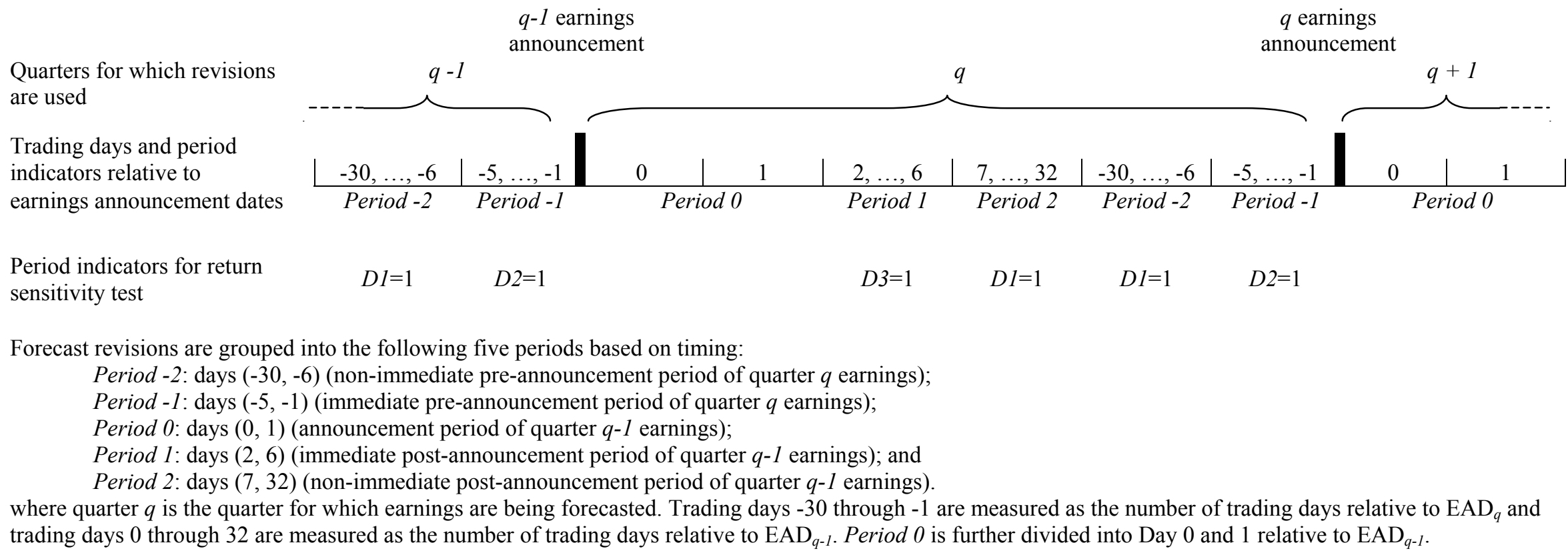


Figure 2

Frequency of management earnings forecast and relative forecast accuracy for firms with and without management forecasts

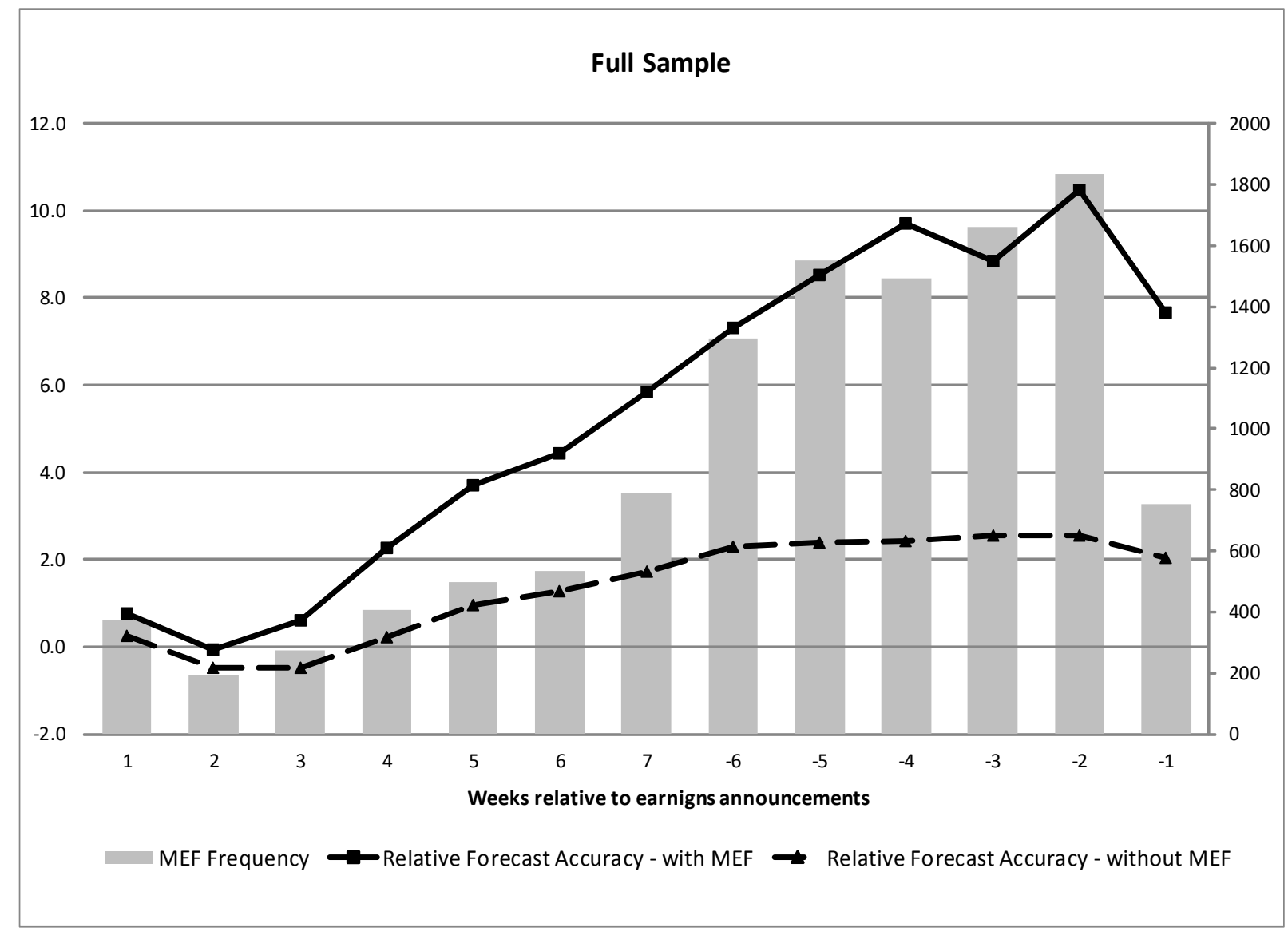

The bar graph presents frequency of management earnings forecasts (MEFs) over the event time. The line graphs present the mean relative forecast accuracy for firms with and without MEF over the event time. Event time is expressed as the number of weeks from the prior-quarter earnings announcement (for revisions made at or before the midpoint of the quarter) or the current quarter earnings announcement (for revisions made after the midpoint of the quarter) except Week 1. Week 1 includes only day (1), the first trading day after the prior-quarter earnings announcement. Relative forecast accuracy is undefined for revisions on the prior-quarter earnings announcement date due to day 0 exclusion. The greater magnitude of relative forecast accuracy represents more accurate analyst forecast relative to the existing consensus forecast. Left-side Y-axis represents relative forecast accuracy and right-side Y-axis represents the frequency of MEFs. 
Figure 3

Abnormal returns around analyst forecast revisions

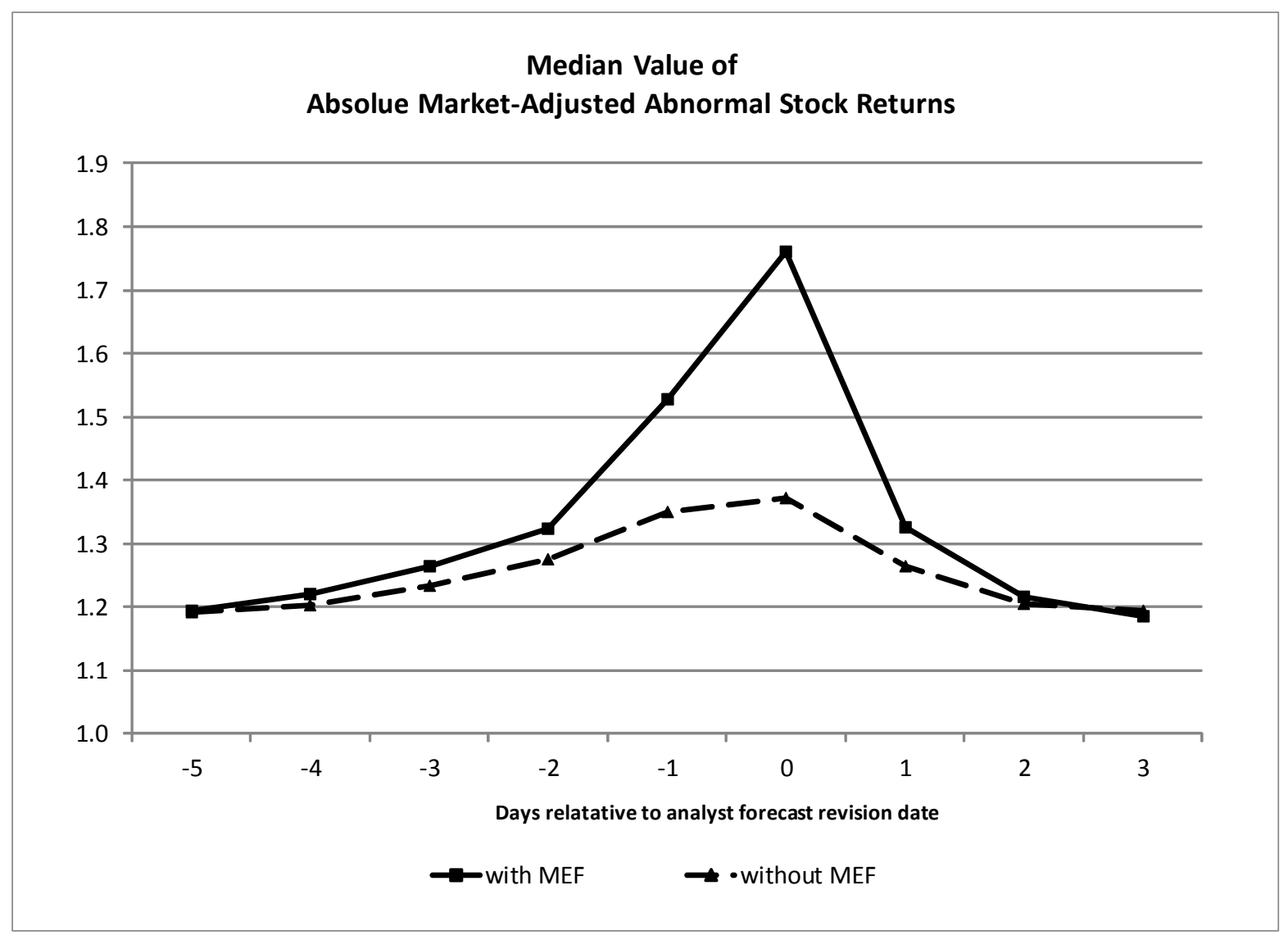

The line graph presents changes in stock returns around analysts' forecast revision date for firms with and without management earnings forecasts (MEFs). The $\mathrm{X}$-axis represents the number of trading days relative to an analyst forecast revision date and Y-axis represents the median of the absolute value of market-adjusted abnormal stock returns on the event day. 
Table 1

Sample selection and distribution

Panel A: Sample selection

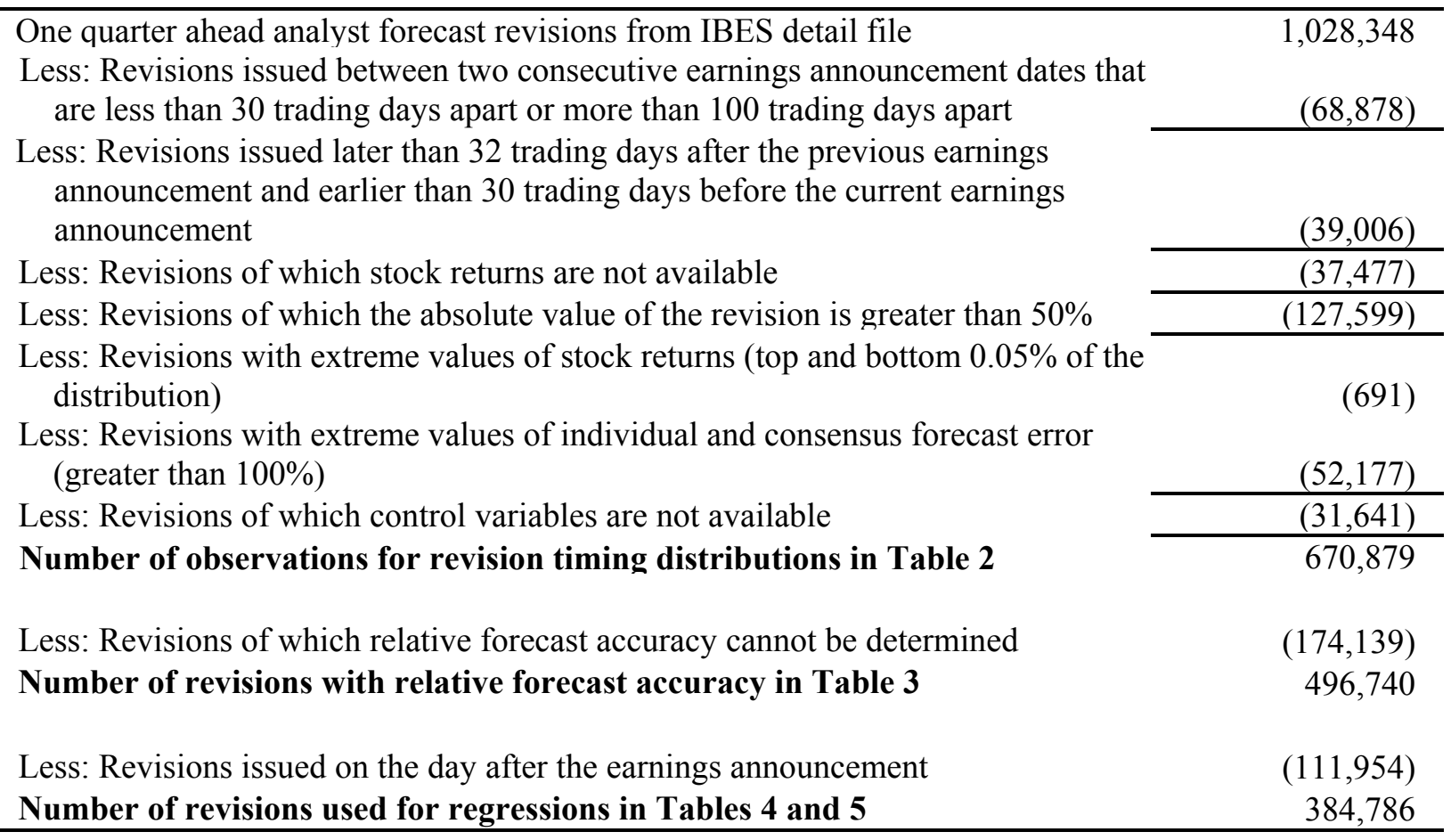

Panel B: Sample distribution by year

\begin{tabular}{rrrc}
\hline Year & Number of Revisions & \# of firms & $\begin{array}{c}\text { Average Number of Analyst } \\
\text { Following the Firm }\end{array}$ \\
\hline 1996 & 19,953 & 2,366 & 2.85 \\
1997 & 20,321 & 2,531 & 2.82 \\
1998 & 24,682 & 2,671 & 3.14 \\
1999 & 24,636 & 2,539 & 3.33 \\
2000 & 19,355 & 2,224 & 3.36 \\
2001 & 28,967 & 2,295 & 4.00 \\
2002 & 29,376 & 2,333 & 3.91 \\
2003 & 35,116 & 2,374 & 4.18 \\
2004 & 44,509 & 2,642 & 4.56 \\
2005 & 46,912 & 2,870 & 4.57 \\
2006 & 49,068 & 3,011 & 4.52 \\
2007 & 49,883 & 3,094 & 4.50 \\
2008 & 55,960 & 3,045 & 4.77 \\
2009 & 48,002 & 2,750 & 5.03 \\
Total & 496,740 & 2,625 & 4.06 \\
\hline
\end{tabular}

Panel A summarizes the sample selection procedure. Panel B presents the sample distribution by year. 
Table 2

Timing of management forecasts and analyst forecast revisions

Panel A: Timing of management forecasts

\begin{tabular}{crrrrrr}
\hline & $1996-2009$ & \multicolumn{3}{c}{ Pre-Reg FD } & \multicolumn{3}{c}{ Post-Reg FD } \\
Period & $\mathrm{N}$ & $\%$ & $\mathrm{~N}$ & $\%$ & $\mathrm{~N}$ & $\%$ \\
\hline-2 & 7,833 & 30.12 & 2,381 & 61.91 & 5,452 & 24.6 \\
-1 & 751 & 2.89 & 324 & 8.42 & 427 & 1.93 \\
(Day 0) & 14,356 & 55.19 & 457 & 11.88 & 13,899 & 62.71 \\
(Day 1) & 374 & 1.44 & 69 & 1.79 & 305 & 1.38 \\
1 & 193 & 0.74 & 51 & 1.33 & 142 & 0.64 \\
2 & 2,503 & 9.62 & 564 & 14.66 & 1,939 & 8.75 \\
\hline Total & 26,010 & 100 & 3,846 & 100 & 22,164 & 100 \\
\hline
\end{tabular}

Panel B: Timing of analyst forecast revisions

\begin{tabular}{|c|c|c|c|c|c|c|}
\hline 1996-2009 & \multicolumn{2}{|c|}{ Full Sample } & \multicolumn{2}{|l|}{ with MEF } & \multicolumn{2}{|c|}{ without MEF } \\
\hline Period & $\mathrm{N}$ & $\%$ & $\mathrm{~N}$ & $\%$ & $\mathrm{~N}$ & $\%$ \\
\hline-2 & 184,413 & 27.49 & 60,369 & 30.72 & 124,044 & 26.15 \\
\hline-1 & 30,159 & 4.50 & 9,190 & 4.68 & 20,969 & 4.42 \\
\hline (Day 0) & 78,776 & 11.74 & 22,600 & 11.50 & 56,176 & 11.84 \\
\hline (Day 1) & 189,940 & 28.31 & 60,169 & 30.62 & 129,771 & 27.36 \\
\hline 1 & 82,830 & 12.35 & 17,669 & 8.99 & 65,161 & 13.74 \\
\hline 2 & 104,761 & 15.62 & 26,499 & 13.49 & 78,262 & 16.50 \\
\hline Total & 670,879 & 100 & 196,496 & 100 & 474,383 & 100 \\
\hline Pre-Reg FD & Full Samp & & with MEF & & without M & \\
\hline Period & $\mathrm{N}$ & $\%$ & $\mathrm{~N}$ & $\%$ & $\mathrm{~N}$ & $\%$ \\
\hline-2 & 48,002 & 33.88 & 11,527 & 43.17 & 36,475 & 31.72 \\
\hline-1 & 6,866 & 4.85 & 1,492 & 5.59 & 5,374 & 4.67 \\
\hline (Day 0) & 5,492 & 3.88 & 652 & 2.44 & 4,840 & 4.21 \\
\hline (Day 1) & 25,719 & 18.15 & 4,262 & 15.96 & 21,457 & 18.66 \\
\hline 1 & 24,227 & 17.10 & 3,588 & 13.44 & 20,639 & 17.95 \\
\hline 2 & 31,393 & 22.15 & 5,183 & 19.41 & 26,210 & 22.79 \\
\hline Total & 141,699 & 100 & 26,704 & 100 & 114,995 & 100 \\
\hline Post-Reg FD & Full Samp & & with MEF & & without M & \\
\hline Period & $\mathrm{N}$ & $\%$ & $\mathrm{~N}$ & $\%$ & $\mathrm{~N}$ & $\%$ \\
\hline-2 & 136,411 & 25.78 & 48,842 & 28.77 & 87,569 & 24.37 \\
\hline-1 & 23,293 & 4.40 & 7,698 & 4.53 & 15,595 & 4.34 \\
\hline (Day 0) & 73,284 & 13.85 & 21,948 & 12.93 & 51,336 & 14.28 \\
\hline (Day 1) & 164,221 & 31.03 & 55,907 & 32.93 & 108,314 & 30.14 \\
\hline 1 & 58,603 & 11.07 & 14,081 & 8.29 & 44,522 & 12.39 \\
\hline 2 & 73,368 & 13.86 & 21,316 & 12.55 & 52,052 & 14.48 \\
\hline Total & 529,180 & 100 & 169,792 & 100 & 359,388 & 100 \\
\hline
\end{tabular}

Panel A reports the frequency of management earnings forecasts (MEFs) over the event time based on five forecast periods between consecutive two quarterly earnings announcement dates (EADs). See Figure 1 for classification of forecast periods. In this table, Period 0 is further divided into Day 0 and Day 1 relative to $E A D_{q-1}$. We define years between 1996 and 2000 as pre-Reg FD and between 2001 and 2009 as post-Reg FD. In Panel B, we further divide sample revisions into revisions by firms that issue management earnings forecasts (with MEF) and those by firms that do not issue management earnings forecasts (without MEF) during the quarter. 
Table 3

Forecast revision timing and relative forecast accuracy

\begin{tabular}{|c|c|c|c|c|c|c|c|c|c|c|c|c|c|}
\hline \multirow{2}{*}{$\frac{1996-2009}{\text { Period }}$} & \multicolumn{3}{|c|}{ Full Sample } & \multicolumn{3}{|c|}{ with MEF } & \multicolumn{3}{|c|}{ without MEF } & \multicolumn{4}{|c|}{ Difference } \\
\hline & $\mathrm{N}$ & Mean & Median & $\mathrm{N}$ & Mean & Median & $\mathrm{N}$ & Mean & Median & Mean & p-value & Median & p-value \\
\hline-2 & 183,147 & 4.62 & 2.08 & 60,166 & 9.05 & 4.88 & 122,981 & 2.46 & 1.08 & 6.60 & $<0.01$ & 3.80 & $<0.01$ \\
\hline-1 & 30,025 & 3.77 & 1.54 & 9,170 & 7.66 & 3.67 & 20,855 & 2.05 & 0.85 & 5.61 & $<0.01$ & 2.82 & $<0.01$ \\
\hline 0 & 111,954 & 0.43 & 0.00 & 38,343 & 0.77 & 0.00 & 73,611 & 0.25 & 0.00 & 0.51 & $<0.01$ & 0.00 & $<0.01$ \\
\hline 1 & 70,643 & -0.38 & 0.00 & 16,122 & -0.07 & 0.00 & 54,521 & 0.47 & 0.00 & 0.40 & $<0.01$ & 0.00 & $<0.01$ \\
\hline 2 & 100,971 & 1.52 & 0.65 & 26,191 & 3.67 & 1.58 & 74,780 & 0.77 & 0.28 & 2.90 & $<0.01$ & 1.30 & $<0.01$ \\
\hline Total & 496,740 & & & 149,992 & & & 346,748 & & & & & & \\
\hline
\end{tabular}

\begin{tabular}{|c|c|c|c|c|c|c|c|c|c|c|c|c|c|}
\hline \multicolumn{14}{|c|}{ Pre-Reg FD } \\
\hline Period & $\mathrm{N}$ & Mean & Median & $\mathrm{N}$ & Mean & Median & $\mathrm{N}$ & Mean & Median & Mean & p-value & Median & p-value \\
\hline-2 & 47,298 & 6.22 & 2.55 & 11,439 & 14.06 & 8.51 & 35,859 & 3.71 & 1.52 & 10.34 & $<0.01$ & 7.00 & $<0.01$ \\
\hline-1 & 6,797 & 5.42 & 2.20 & 1,480 & 11.96 & 7.12 & 5,317 & 3.60 & 1.43 & 8.36 & $<0.01$ & 5.69 & $<0.01$ \\
\hline 0 & 6,546 & 1.20 & 0.00 & 1,265 & 1.66 & 0.00 & 5,281 & 1.10 & 0.00 & 0.56 & 0.10 & 0.00 & 0.02 \\
\hline 1 & 19,178 & -0.19 & 0.00 & 3,104 & 0.32 & 0.00 & 16,074 & -0.29 & 0.00 & 0.61 & $<0.01$ & 0.00 & 0.03 \\
\hline 2 & 29,128 & 2.06 & 0.66 & 5,010 & 5.56 & 2.48 & 24,118 & 1.33 & 0.38 & 4.23 & $<0.01$ & 2.10 & $<0.01$ \\
\hline Total & 108,947 & & & 22,298 & & & 86,649 & & & & & & \\
\hline
\end{tabular}

\begin{tabular}{|c|c|c|c|c|c|c|c|c|c|c|c|c|c|}
\hline Period & $\mathrm{N}$ & Mean & Median & $\mathrm{N}$ & Mean & Median & $\mathrm{N}$ & Mean & Median & Mean & p-value & Median & p-value \\
\hline-2 & 135,849 & 4.07 & 1.90 & 48,727 & 7.88 & 4.22 & 87,122 & 1.94 & 0.87 & 5.94 & $<0.01$ & 3.35 & $<0.01$ \\
\hline-1 & 23,228 & 3.28 & 1.39 & 7,690 & 6.84 & 3.21 & 15,538 & 1.52 & 0.66 & 5.31 & $<0.01$ & 2.54 & $<0.01$ \\
\hline 0 & 105,408 & 0.38 & 0.00 & 37,078 & 0.74 & 0.00 & 68,330 & 0.19 & 0.00 & 0.55 & $<0.01$ & 0.00 & $<0.01$ \\
\hline 1 & 51,465 & -0.45 & 0.00 & 13,018 & -0.16 & 0.00 & 38,447 & -0.55 & 0.00 & 0.39 & $<0.01$ & 0.00 & $<0.01$ \\
\hline 2 & 71,843 & 1.31 & 0.64 & 21,181 & 3.22 & 1.42 & 50,662 & 0.50 & 0.22 & 2.72 & $<0.01$ & 1.19 & $<0.01$ \\
\hline Total & 387,793 & & & 127,694 & & & 260,099 & & & & & & \\
\hline
\end{tabular}

This table reports summary statistics of relative analyst forecast accuracy, $R F A$, over five forecast periods. See Figure 1 for classification of forecast periods. All variables are defined in the Appendix. $R F A$ on day $(0)$ is not defined due to day 0 exclusion. We test the difference in $R F A$ between revisions by firms that issue management earnings forecasts (with MEF) and those by firms that do not issue management earnings forecasts (without MEF) during the quarter. We define years between 1996 and 2000 and pre-Reg FD and between 2001 and 2009 as post-Reg FD. Test of difference in means is based on t-test and test of difference in median is based on Wilcoxon rank sum test. Two-tailed p-values are reported. 


\section{Table 4}

\section{Forecast revision timing and relative forecast accuracy - Regression Analysis}

\begin{tabular}{|c|c|c|c|c|c|c|c|c|c|c|c|c|}
\hline & \multicolumn{3}{|c|}{ Full Sample } & \multicolumn{3}{|c|}{ with MEF } & \multicolumn{3}{|c|}{ without MEF } & \multirow{2}{*}{\multicolumn{3}{|c|}{$\begin{array}{c}\text { Difference between revisions } \\
\text { with and without MEF }\end{array}$}} \\
\hline & coeff. & t-value & & coeff. & t-value & & coeff. & t-value & & $\begin{array}{r}\text { with and } \\
\text { difference }\end{array}$ & & \\
\hline DPeriod -2 & 9.087 & 17.93 & $* * *$ & 16.766 & 16.10 & $* * *$ & 4.944 & 10.73 & $* * *$ & 11.822 & 11.09 & $* * *$ \\
\hline DPeriod -1 & 8.344 & 14.17 & $* * *$ & 15.617 & 12.57 & $* * *$ & 4.596 & 10.16 & $* * *$ & 11.021 & 8.88 & $* * *$ \\
\hline DPeriod 1 & 3.926 & 8.81 & $* * *$ & 7.462 & 7.39 & $* * *$ & 1.879 & 4.51 & $* * *$ & 5.583 & 5.41 & $* * *$ \\
\hline DPeriod 2 & 5.942 & 13.02 & $* * *$ & 11.448 & 11.20 & $* * *$ & 3.207 & 7.73 & $* * *$ & 8.241 & 7.96 & $* * *$ \\
\hline SIZE & -0.764 & -8.83 & $* * *$ & -1.169 & -7.57 & $* * *$ & -0.289 & -4.34 & $* * *$ & -0.880 & -5.59 & $* * *$ \\
\hline$B M$ & -0.099 & -0.49 & & 0.638 & 1.08 & & 0.257 & 1.57 & & 0.381 & 0.68 & \\
\hline COVERAGE & 0.834 & 4.10 & $* * *$ & 0.668 & 2.22 & $* *$ & -0.090 & -0.65 & & 0.757 & 2.41 & $* *$ \\
\hline SPECIAL & -2.598 & -1.55 & & -1.451 & -0.42 & & -2.467 & -1.65 & $*$ & 1.016 & 0.28 & \\
\hline LOSS & -1.030 & -4.28 & $* * *$ & -0.077 & -0.12 & & -0.902 & -4.20 & $* * *$ & 0.825 & 1.26 & \\
\hline DIFFICULTY & -0.119 & -0.55 & & -0.715 & -1.29 & & 0.568 & 2.63 & $* * *$ & -1.283 & -2.16 & $* *$ \\
\hline $\mathrm{N}$ & 384,786 & & & 111,649 & & & 273,137 & & & & & \\
\hline Adj. R-sq. & 0.062 & & & 0.196 & & & 0.020 & & & & & \\
\hline \multicolumn{2}{|c|}{ DPeriod $-2=$ DPeriod -1} & 3.42 & $* * *$ & & 2.37 & $* *$ & & 2.34 & $* *$ & & & \\
\hline \multicolumn{2}{|c|}{ DPeriod $-2=$ DPeriod 1} & 23.88 & $* * *$ & & 24.82 & $* * *$ & & 19.67 & $* * *$ & & & \\
\hline \multicolumn{2}{|c|}{ DPeriod $-2=$ DPeriod 2} & 19.44 & $* * *$ & & 16.39 & $* * *$ & & 13.97 & $* * *$ & & & \\
\hline \multicolumn{2}{|c|}{ DPeriod $-1=$ DPeriod 1} & 14.26 & $* * *$ & & 14.39 & $* * *$ & & 14.10 & $* * *$ & & & \\
\hline \multicolumn{2}{|c|}{ DPeriod $-1=$ DPeriod 2} & 8.81 & $* * *$ & & 7.31 & $* * *$ & & 8.31 & $* * *$ & & & \\
\hline \multicolumn{2}{|c|}{ DPeriod $1=$ DPeriod 2} & 13.29 & $* * *$ & & 11.27 & $* * *$ & & 10.33 & $* * *$ & & & \\
\hline
\end{tabular}

This table reports the results of the regression of relative forecast accuracy $(R F A)$ on period indicators and control variables. All variables are defined in the Appendix. We divide sample revisions into revisions by firms that issue management earnings forecasts (with MEF) and those by firms that do not issue management earnings forecasts (without MEF) during the quarter. All test statistics and significance levels are calculated based on standard errors adjusted by a two-dimensional cluster at the analyst and quarter levels. $* * *, * * *$ denote significance at the $1 \%, 5 \%$, and $10 \%$ levels, respectively (two-tailed). 
Table 5

Forecast revision timing and return sensitivity to forecast revisions

Panel A: Full sample period: 1996-2009

\begin{tabular}{|c|c|c|c|c|c|c|c|c|c|c|c|c|}
\hline & \multicolumn{3}{|c|}{ Full Sample } & \multicolumn{3}{|c|}{ with MEF } & \multicolumn{3}{|c|}{ without MEF } & \multirow{2}{*}{\multicolumn{3}{|c|}{$\begin{array}{l}\text { Difference between revisions } \\
\text { with and without MEF }\end{array}$}} \\
\hline & coeff. & t-value & & coeff. & t-value & & coeff. & t-value & & & & \\
\hline Intercept & 0.057 & 0.36 & & -0.475 & -1.49 & & 0.238 & 1.68 & $*$ & -0.713 & -2.32 & $* *$ \\
\hline$F R * D 1$ & 0.069 & 20.03 & $* * *$ & 0.117 & 18.10 & $* * *$ & 0.042 & 15.82 & $* * *$ & 0.076 & 12.08 & $* * *$ \\
\hline$F R^{*} D 2$ & 0.045 & 7.62 & $* * *$ & 0.091 & 8.45 & $* * *$ & 0.020 & 5.00 & $* * *$ & 0.071 & 7.02 & $* * *$ \\
\hline$F R * D 3$ & 0.015 & 5.88 & $* * *$ & 0.008 & 1.62 & & 0.017 & 6.66 & $* * *$ & -0.010 & -2.04 & $* *$ \\
\hline$S I Z E$ & 0.008 & 0.31 & & 0.024 & 0.46 & & -0.014 & -0.73 & & 0.038 & 0.76 & \\
\hline$B M$ & 0.187 & 3.05 & $* * *$ & 0.519 & 3.20 & $* * *$ & 0.092 & 1.39 & & 0.427 & 2.39 & $* *$ \\
\hline COVERAGE & -0.092 & -1.75 & $*$ & -0.009 & -0.07 & & -0.049 & -1.03 & & 0.039 & 0.30 & \\
\hline SPECIAL & -0.054 & -0.14 & & -0.610 & -0.67 & & -0.134 & -0.32 & & -0.476 & -0.47 & \\
\hline LOSS & -0.102 & -1.06 & & -0.042 & -0.19 & & -0.168 & -1.55 & & 0.126 & 0.50 & \\
\hline DIFFICULTY & 0.221 & 4.26 & $* * *$ & 0.219 & 1.32 & & 0.142 & 2.99 & $* * *$ & 0.077 & 0.45 & \\
\hline $\mathrm{N}$ & 384,786 & & & 111,649 & & & 273,137 & & & & & \\
\hline Adj. R-sq. & 0.029 & & & 0.075 & & & 0.012 & & & & & \\
\hline$F R * D 1=F R * D 2$ & & 4.43 & $* * *$ & & 2.43 & $* *$ & & 4.99 & $* * *$ & & & \\
\hline$F R * D 2=F R * D 3$ & & 5.00 & $* * *$ & & 7.43 & $* * *$ & & 0.58 & & & & \\
\hline$F R^{*} D 3=F R^{*} D 1$ & & 14.09 & $* * *$ & & 15.98 & $* * *$ & & 7.18 & $* * *$ & & & \\
\hline
\end{tabular}


Panel B: All forecast revisions: Pre- and Post-Reg FD periods

\begin{tabular}{|c|c|c|c|c|c|c|c|c|c|c|c|}
\hline & \multicolumn{3}{|c|}{ Full Sample } & \multicolumn{3}{|c|}{ with MEF } & \multicolumn{3}{|c|}{ without MEF } & \multirow{2}{*}{\multicolumn{2}{|c|}{$\begin{array}{l}\text { Difference between revisions } \\
\text { with and without MEF } \\
\text { difference t-value }\end{array}$}} \\
\hline & coeff. & t-value & & coeff. & $\mathrm{t}$-value & & coeff. & $\mathrm{t}$-value & & & \\
\hline Pre-Reg FD & & & & & & & & & & & \\
\hline Intercept & -0.082 & -0.27 & & -0.938 & -1.43 & & 0.110 & 0.38 & & -1.049 & -1.63 \\
\hline$F R * D 1$ & 0.049 & 10.08 & $* * *$ & 0.091 & 8.01 & $* * *$ & 0.029 & 10.62 & $* * *$ & 0.062 & $5.87 * * *$ \\
\hline$F R * D 2$ & 0.029 & 3.53 & $* * *$ & 0.055 & 2.44 & $* *$ & 0.017 & 2.51 & $* *$ & 0.039 & 1.64 \\
\hline$F R^{*} D 3$ & 0.009 & 1.77 & $*$ & 0.010 & 0.96 & & 0.009 & 1.58 & & 0.001 & 0.08 \\
\hline Control variables & & Included & & & Included & & & Included & & & \\
\hline $\mathrm{N}$ & 102,401 & & & 21,033 & & & 81,368 & & & & \\
\hline Adj. R-sq. & 0.014 & & & 0.040 & & & 0.005 & & & & \\
\hline$F R^{*} D 1=F R^{*} D 2$ & & 2.34 & $* *$ & & 1.62 & & & 1.71 & $*$ & & \\
\hline$F R^{*} D 2=F R^{*} D 3$ & & 2.28 & $* *$ & & 1.75 & $*$ & & 0.98 & & & \\
\hline$F R^{*} D 3=F R^{*} D 1$ & & 5.59 & $* * *$ & & 6.85 & $* * *$ & & 3.24 & $* * *$ & & \\
\hline Post-Reg FD & & & & & & & & & & & \\
\hline Intercept & 0.072 & 0.38 & & -0.374 & -1.03 & & 0.255 & 1.55 & & -0.629 & $-1.83 *$ \\
\hline$F R * D 1$ & 0.077 & 18.47 & $* * *$ & 0.125 & 16.10 & $* * *$ & 0.047 & 14.10 & $* * *$ & 0.077 & $10.06 * * *$ \\
\hline$F R * D 2$ & 0.051 & 6.89 & $* * *$ & 0.102 & 8.52 & $* * *$ & 0.021 & 4.25 & $* * *$ & 0.081 & $7.33 * * *$ \\
\hline$F R * D 3$ & 0.017 & 5.98 & $* * *$ & 0.007 & 1.38 & & 0.020 & 7.65 & $* * *$ & -0.013 & $-2.63 * * *$ \\
\hline Control variables & & Included & & & Included & & & Included & & & \\
\hline $\mathrm{N}$ & 282,385 & & & 90,616 & & & 191,769 & & & & \\
\hline Adj. R-sq. & 0.037 & & & 0.088 & & & 0.015 & & & & \\
\hline$F R^{*} D 1=F R^{*} D 2$ & & 3.97 & $* * *$ & & 1.98 & $* *$ & & 4.88 & $* * *$ & & \\
\hline$F R^{*} D 2=F R^{*} D 3$ & & 4.56 & $* * *$ & & 7.79 & $* * *$ & & 0.14 & & & \\
\hline$F R^{*} D 3=F R^{*} D 1$ & & 13.72 & $* * *$ & & 14.46 & $* * *$ & & 6.89 & $* * *$ & & \\
\hline
\end{tabular}

This table reports the results of the following regression of stock returns on analyst forecast revisions at different points in event time relative to the earnings announcement date and control variables. All variables are defined in the Appendix. We divide sample revisions into revisions by firms that issue management earnings forecasts (with MEF) and those by firms that do not issue management earnings forecasts (without MEF) during the quarter. Panel A presents regression results for revisions over the entire sample period (1996-2009), and Panel B presents results for revisions during the pre- and post-Reg FD periods. We define years between 1996 and 2000 and pre-Reg FD period and between 2001 and 2009 as post-Reg FD period. All test statistics and significance levels are calculated based on standard errors adjusted by a two-dimensional cluster at the analyst and quarter levels. ${ }^{* * *}, * *, *$ denote significance at the $1 \%, 5 \%$, and $10 \%$ levels, respectively (two-tailed). 
Table 6

Upward and downward revisions: forecast revision timing and return sensitivity to forecast revisions

Panel A: Upward revisions

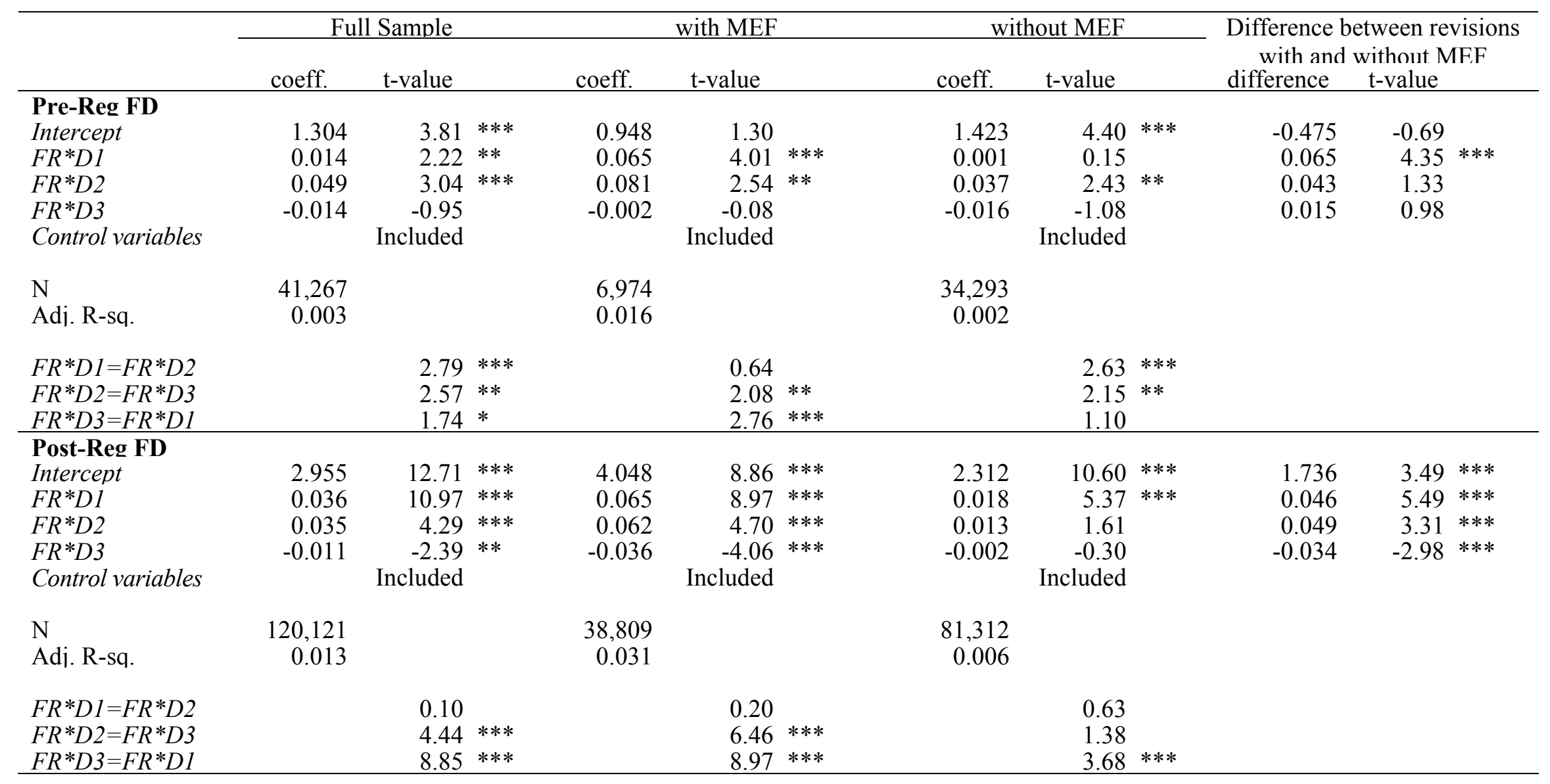


Panel B: Downward revisions

\begin{tabular}{|c|c|c|c|c|c|c|c|c|c|c|c|c|}
\hline & \multicolumn{3}{|c|}{ Full Sample } & \multicolumn{3}{|c|}{ with MEF } & \multicolumn{3}{|c|}{ without MEF } & \multicolumn{3}{|c|}{$\begin{array}{c}\text { Difference between revisions } \\
\text { with and without MEF }\end{array}$} \\
\hline & coeff. & t-value & & coeff. & t-value & & coeff. & t-value & & difference & t-value & \\
\hline \multicolumn{13}{|l|}{ Pre-Reg FD } \\
\hline Intercept & -0.954 & -2.19 & $* *$ & -2.741 & -2.31 & $* *$ & -0.836 & -2.51 & $* *$ & -1.906 & -1.63 & \\
\hline$F R^{*} D 1$ & 0.039 & 5.75 & $* * *$ & 0.052 & 3.45 & $* * *$ & 0.016 & 3.89 & $* * *$ & 0.035 & 2.29 & $* *$ \\
\hline$F R * D 2$ & -0.004 & -0.44 & & -0.001 & -0.06 & & -0.019 & -1.76 & $*$ & 0.018 & 0.72 & \\
\hline$F R * D 3$ & -0.008 & -1.31 & & -0.051 & -2.83 & $* * *$ & -0.006 & -0.83 & & -0.045 & -2.20 & $* *$ \\
\hline Control variables & & Included & & & Included & & & Included & & & & \\
\hline $\mathrm{N}$ & 61,134 & & & 14,059 & & & 47,075 & & & & & \\
\hline Adj. R-sq. & 0.006 & & & 0.011 & & & 0.002 & & & & & \\
\hline$F R * D 1=F R^{*} D 2$ & & 4.07 & $* * *$ & & 2.32 & $* *$ & & 3.49 & $* * *$ & & & \\
\hline$F R^{*} D 2=F R^{*} D 3$ & & 0.41 & & & 1.87 & $*$ & & 1.14 & & & & \\
\hline$F R^{*} D 3=F R^{*} D 1$ & & 5.06 & $* * *$ & & 8.38 & $* * *$ & & 2.62 & $* * *$ & & & \\
\hline \multicolumn{13}{|l|}{ Post-Reg FD } \\
\hline Intercept & -1.872 & -8.73 & $* * *$ & -3.540 & -6.82 & $* * *$ & -1.212 & -7.14 & $* * *$ & -2.328 & -4.51 & $* * *$ \\
\hline$F R^{*} D 1$ & 0.065 & 10.14 & $* * *$ & 0.101 & 8.09 & $* * *$ & 0.034 & 6.50 & $* * *$ & 0.067 & 5.35 & $* * *$ \\
\hline$F R * D 2$ & 0.023 & 2.30 & $* *$ & 0.065 & 3.43 & $* * *$ & -0.006 & -0.88 & & 0.071 & 3.75 & $* * *$ \\
\hline$F R * D 3$ & -0.008 & -1.62 & & -0.030 & -3.75 & $* * *$ & -0.002 & -0.58 & & -0.028 & -3.70 & $* * *$ \\
\hline Control variables & & Included & & & Included & & & Included & & & & \\
\hline $\mathrm{N}$ & 162,264 & & & 51,807 & & & 110,457 & & & & & \\
\hline Adj. R-sq. & 0.018 & & & 0.039 & & & 0.006 & & & & & \\
\hline$F R * D 1=F R * D 2$ & & 4.73 & $* * *$ & & 1.91 & $*$ & & 5.83 & $* * *$ & & & \\
\hline$F R * D 2=F R * D 3$ & & 2.98 & $* * *$ & & 5.23 & $* * *$ & & 0.46 & & & & \\
\hline$F R * D 3=F R^{*} D 1$ & & 10.63 & $* * *$ & & 11.87 & $* * *$ & & 5.45 & $* * *$ & & & \\
\hline
\end{tabular}

This table reports the results of the regression of stock returns on analyst forecast revisions at different points in event time relative to the earnings announcement date and control variables. All variables are defined in the Appendix. We divide sample revisions into revisions by firms that issue management earnings forecasts (with MEF) and those by firms that do not issue management earnings forecasts (without MEF) during the quarter. Panel A (B) presents results for upward (downward) revisions during the pre- and post-Reg FD periods. We define years between 1996 and 2000 and pre-Reg FD and between 2001 and 2009 as post-Reg FD. All test statistics and significance levels are calculated based on standard errors adjusted by a two-dimensional cluster at the analyst and quarter levels. $* * *, * *, *$ denote significance at the $1 \%, 5 \%$, and $10 \%$ levels, respectively (two-tailed). 
Table 7

Forecast revision timing and return sensitivity to forecast revisions after controlling for news from management forecasts

Panel A. Return sensitivity to forecast revisions after controlling for management forecasts

\begin{tabular}{|c|c|c|c|c|c|c|c|c|}
\hline \multirow{3}{*}{ Intercept } & \multicolumn{2}{|c|}{ Full Sample } & \multicolumn{3}{|c|}{ Pre-FD } & \multicolumn{3}{|c|}{ Post-FD } \\
\hline & coeff. & t-value & coeff. & t-value & & coeff. & t-value & \\
\hline & 0.155 & 1.02 & -0.023 & -0.08 & & 0.201 & 1.08 & \\
\hline$F R * D 1$ & 0.044 & $17.32 * * *$ & 0.030 & 10.94 & $* * *$ & 0.049 & 15.48 & $* * *$ \\
\hline$F R * D 2$ & 0.018 & $4.23 * * *$ & 0.005 & 0.53 & & 0.023 & 4.89 & $* * *$ \\
\hline$F R^{*} D 3$ & 0.016 & $6.68 * * *$ & 0.009 & 1.81 & $*$ & 0.018 & 7.09 & $* * *$ \\
\hline$M F^{*} D 1$ & 0.149 & $15.64 * * *$ & 0.140 & 6.48 & $* * *$ & 0.151 & 14.24 & $* * *$ \\
\hline$M F^{*} D 2$ & 0.306 & $9.65 * * *$ & 0.419 & 8.93 & $* * *$ & 0.283 & 8.12 & $* * *$ \\
\hline$M F^{*} D 3$ & -0.009 & -0.99 & -0.012 & -0.28 & & -0.011 & -1.12 & \\
\hline$S I Z E$ & -0.013 & -0.57 & -0.016 & -0.41 & & -0.013 & -0.47 & \\
\hline$B M$ & 0.131 & $2.26 * *$ & 0.079 & 0.64 & & 0.153 & 2.44 & $* *$ \\
\hline COVERAGE & -0.026 & -0.52 & 0.085 & 1.03 & & -0.055 & -0.88 & \\
\hline SPECIAL & -0.412 & -1.06 & -2.118 & -2.56 & $* *$ & 0.065 & 0.16 & \\
\hline LOSS & -0.110 & -1.23 & 0.006 & 0.03 & & -0.155 & -1.59 & \\
\hline DIFFICULTY & 0.135 & $2.65 * * *$ & 0.151 & 1.16 & & 0.141 & 2.51 & $* *$ \\
\hline $\mathrm{N}$ & 380,854 & & 100,942 & & & 279,912 & & \\
\hline Adj. R-sq. & 0.050 & & 0.032 & & & 0.059 & & \\
\hline$F R * D 1=F R * D 2$ & & $6.25 * * *$ & & 2.80 & $* * *$ & & 5.76 & $* * *$ \\
\hline$F R * D 2=F R * D 3$ & & 0.36 & & 0.52 & & & 0.82 & \\
\hline$F R^{*} D 3=F R^{*} D 1$ & & $8.65 * * *$ & & 3.72 & $* * *$ & & 8.25 & $* * *$ \\
\hline
\end{tabular}


Panel B. Return sensitivity to forecast revisions for firms with management forecasts

\begin{tabular}{|c|c|c|c|c|c|c|c|c|c|}
\hline & coeff. & t-value & & coeff. & t-value & & Coeff. & t-value & \\
\hline Intercept & -0.080 & -0.25 & & -0.156 & -0.48 & & -0.194 & -0.61 & \\
\hline$F R * D 1$ & 0.059 & 12.95 & $* * *$ & 0.059 & 12.85 & $* * *$ & 0.059 & 13.01 & $* * *$ \\
\hline$F R * D 2$ & 0.014 & 1.56 & & 0.014 & 1.54 & & 0.014 & 1.53 & \\
\hline$F R * D 3$ & 0.011 & 2.47 & $* *$ & 0.011 & 2.54 & $* *$ & 0.011 & 2.49 & $* *$ \\
\hline$M F^{*} D 1$ & 0.134 & 14.92 & $* * *$ & 0.138 & 14.37 & $* * *$ & 0.140 & 14.84 & $* * *$ \\
\hline$M F^{*} D 2$ & 0.310 & 9.36 & $* * *$ & 0.304 & 9.84 & $* * *$ & 0.304 & 9.82 & $* * *$ \\
\hline$M F^{*} D 3$ & -0.005 & -0.51 & & 0.004 & 0.40 & & 0.005 & 0.48 & \\
\hline$M F^{*} F R^{*} D 1$ & & & & 0.032 & 1.11 & & & & \\
\hline$M F^{*} F R^{*} D 2$ & & & & -0.067 & -0.59 & & & & \\
\hline$M F^{*} F R^{*} D 3$ & & & & 0.070 & 1.84 & $*$ & & & \\
\hline $\operatorname{Max}\left(M F^{*} F R, 0\right) * D 1$ & & & & & & & 0.039 & 1.32 & \\
\hline $\operatorname{Max}\left(M F^{*} F R, 0\right) * D 2$ & & & & & & & -0.065 & -0.57 & \\
\hline $\operatorname{Max}\left(M F^{*} F R, 0\right) * D 3$ & & & & & & & 0.075 & 1.88 & $*$ \\
\hline $\operatorname{Min}\left(0, M F^{*} F R\right)^{*} D 1$ & & & & & & & -0.304 & -2.14 & $* *$ \\
\hline $\operatorname{Min}\left(0, M F^{*} F R\right) * D 2$ & & & & & & & -0.180 & -0.37 & \\
\hline $\operatorname{Min}\left(0, M F^{*} F R\right) * D 3$ & & & & & & & -0.013 & -0.13 & \\
\hline$S I Z E$ & -0.023 & -0.45 & & -0.015 & -0.29 & & -0.011 & -0.22 & \\
\hline$B M$ & 0.390 & 2.46 & $* *$ & 0.391 & 2.48 & $* *$ & 0.388 & 2.47 & $* *$ \\
\hline COVERAGE & 0.054 & 0.44 & & 0.047 & 0.39 & & 0.045 & 0.36 & \\
\hline SPECIAL & -1.382 & -1.48 & & -1.408 & -1.48 & & -1.435 & -1.51 & \\
\hline LOSS & -0.131 & -0.58 & & -0.126 & -0.56 & & -0.132 & -0.58 & \\
\hline DIFFICULTY & 0.093 & 0.49 & & 0.085 & 0.45 & & 0.077 & 0.40 & \\
\hline $\mathrm{N}$ & 110,295 & & & 110,295 & & & 110,295 & & \\
\hline Adj. R-sq. & 0.108 & & & 0.108 & & & 0.108 & & \\
\hline$F R * D 1=F R * D 2$ & & 4.75 & $* * *$ & & 4.73 & $* * *$ & & 4.69 & $* * *$ \\
\hline$F R * D 2=F R * D 3$ & & 0.30 & & & 0.22 & & & 0.24 & \\
\hline$F R * D 3=F R * D 1$ & & 8.49 & $* * *$ & & 8.22 & $* * *$ & & 8.38 & $* * *$ \\
\hline
\end{tabular}


Panel C. Return sensitivity to forecast revisions for firms with management forecasts - firm fixed effect model

\begin{tabular}{|c|c|c|c|c|c|c|c|c|c|}
\hline & coeff. & t-value & & coeff. & t-value & & Coeff. & t-value & \\
\hline$F R * D 1$ & 0.054 & 32.12 & $* * *$ & 0.054 & 32.13 & $* * *$ & 0.053 & 31.92 & $* * *$ \\
\hline$F R * D 2$ & 0.007 & 1.58 & & 0.007 & 1.58 & & 0.007 & 1.57 & \\
\hline$F R * D 3$ & 0.012 & 3.44 & $* * *$ & 0.013 & 3.58 & $* * *$ & 0.012 & 3.49 & $* * *$ \\
\hline$M F^{*} D 1$ & 0.133 & 54.67 & $* * *$ & 0.138 & 52.65 & $* * *$ & 0.139 & 52.85 & $* * *$ \\
\hline$M F^{*} D 2$ & 0.296 & 32.80 & $* * *$ & 0.293 & 31.69 & $* * *$ & 0.293 & 31.70 & $* * *$ \\
\hline$M F^{*} D 3$ & -0.004 & -0.63 & & 0.004 & 0.55 & & 0.004 & 0.61 & \\
\hline$M F^{*} F R^{*} D 1$ & & & & 0.035 & 4.96 & $* * *$ & & & \\
\hline$M F^{*} F R^{*} D 2$ & & & & -0.055 & -2.06 & $* *$ & & & \\
\hline$M F^{*} F R^{*} D 3$ & & & & 0.061 & 2.77 & $* * *$ & & & \\
\hline $\operatorname{Max}\left(M F^{*} F R, 0\right) * D 1$ & & & & & & & 0.041 & 5.65 & $* * *$ \\
\hline $\operatorname{Max}\left(M F^{*} F R, 0\right) * D 2$ & & & & & & & -0.054 & -1.98 & $* *$ \\
\hline $\operatorname{Max}\left(M F^{*} F R, 0\right) * D 3$ & & & & & & & 0.064 & 2.81 & $* * *$ \\
\hline $\operatorname{Min}\left(0, M F^{*} F R\right) * D 1$ & & & & & & & -0.217 & -3.85 & $* * *$ \\
\hline $\operatorname{Min}\left(0, M F^{*} F R\right)^{*} D 2$ & & & & & & & -0.159 & -0.43 & \\
\hline $\operatorname{Min}\left(0, M F^{*} F R\right)^{*} D 3$ & & & & & & & 0.019 & 0.15 & \\
\hline$S I Z E$ & -0.643 & -12.10 & $* * *$ & -0.629 & -11.82 & $* * *$ & -0.623 & -11.70 & $* * *$ \\
\hline$B M$ & 0.290 & 2.43 & $* *$ & 0.293 & 2.45 & $* *$ & 0.288 & 2.41 & $* *$ \\
\hline COVERAGE & -0.397 & -4.94 & $* * *$ & -0.410 & -5.10 & $* * *$ & -0.414 & -5.14 & $* * *$ \\
\hline SPECIAL & -1.957 & -2.64 & $* * *$ & -2.016 & -2.72 & $* * *$ & -2.034 & -2.75 & $* * *$ \\
\hline LOSS & 0.192 & 2.12 & $* *$ & 0.196 & 2.17 & $* *$ & 0.194 & 2.15 & $* *$ \\
\hline DIFFICULTY & 0.058 & 0.63 & & 0.053 & 0.58 & & 0.050 & 0.54 & \\
\hline Firm fixed-effects & Yes & & & Yes & & & Yes & & \\
\hline $\mathrm{N}$ & 110,295 & & & 110,295 & & & 110,295 & & \\
\hline Adj. R-sq. & 0.096 & & & 0.097 & & & 0.097 & & \\
\hline$F R * D 1=F R * D 2$ & & 9.68 & $* * *$ & & 9.69 & $* * *$ & & 9.63 & $* * *$ \\
\hline$F R * D 2=F R * D 3$ & & 0.84 & & & 0.94 & & & 0.89 & \\
\hline$F R^{*} D 3=F R^{*} D 1$ & & 10.90 & $* * *$ & & 10.73 & $* * *$ & & 10.68 & $* * *$ \\
\hline
\end{tabular}

This table reports the results of the regression of stock returns on analyst forecast revisions at different points in event time relative to the earnings announcement date and control variables. All variables are defined in the Appendix. In Panel A, we define years between 1996 and 2000 and pre-Reg FD period and between 2001 and 2009 as post-Reg FD period. Test statistics and significance levels are calculated based on standard errors adjusted by a two-dimensional cluster at the analyst and quarter levels. $* * *, * *, *$ denote significance at the $1 \%, 5 \%$, and $10 \%$ levels, respectively (two-tailed). 
Table 8

Propensity-score matching: forecast timing and return sensitivity to forecast revisions

\begin{tabular}{|c|c|c|c|c|c|c|c|c|c|c|c|c|c|c|c|c|c|c|}
\hline & \multirow{2}{*}{\multicolumn{3}{|c|}{$\begin{array}{c}\text { Matched } \\
\text { Guidance Firm } \\
\text { Sample }\end{array}$}} & \multirow{2}{*}{\multicolumn{3}{|c|}{$\begin{array}{c}\text { Matched } \\
\text { Non-Guidance Firm } \\
\text { Sample }\end{array}$}} & \multirow{2}{*}{\multicolumn{3}{|c|}{$\begin{array}{c}\text { Difference between } \\
\text { matched guidance and } \\
\text { non-guidance }\end{array}$}} & \multicolumn{9}{|c|}{$\begin{array}{l}\text { Pooled Matched Sample } \\
\text { after controlling for management forecasts }\end{array}$} \\
\hline & & & & & & & & & & \multicolumn{3}{|c|}{$\begin{array}{l}\text { Matched Sample } \\
\text { Firms }\end{array}$} & \multicolumn{3}{|c|}{ Pre-FD } & \multicolumn{3}{|c|}{ Post-FD } \\
\hline & coeff. & t-value & & coeff. & t-value & & differenc & t-value & & coeff. & t-value & & coeff. & t-value & & coeff. & t-value & \\
\hline Intercept & -0.348 & -0.47 & & 0.673 & 1.97 & $* *$ & -1.021 & -1.29 & & 0.233 & 0.59 & & -1.583 & -2.89 & $* * *$ & 0.779 & 1.84 & $*$ \\
\hline$F R^{*} D 1$ & 0.112 & 10.69 & $* * *$ & 0.041 & 7.92 & $* * *$ & 0.071 & 6.98 & $* * *$ & 0.050 & 8.92 & $* * *$ & 0.032 & 3.66 & $* * *$ & 0.055 & 7.70 & $* * *$ \\
\hline$F R^{*} D 2$ & 0.060 & 3.00 & $* * *$ & 0.019 & 1.65 & $*$ & 0.041 & 1.83 & $*$ & 0.021 & 2.28 & $* *$ & -0.012 & -0.46 & & 0.029 & 3.27 & $* * *$ \\
\hline$F R^{*} D 3$ & 0.021 & 3.32 & $* * *$ & 0.023 & 4.98 & $* * *$ & -0.002 & -0.24 & & 0.022 & 5.14 & $* * *$ & 0.013 & 1.16 & & 0.024 & 5.16 & $* * *$ \\
\hline$M F^{*} D 1$ & & & & & & & & & & 0.128 & 6.07 & $* * *$ & 0.054 & 2.61 & $* * *$ & 0.159 & 7.43 & $* * *$ \\
\hline$M F^{*} D 2$ & & & & & & & & & & 0.181 & 2.65 & $* * *$ & 0.080 & 1.17 & & 0.256 & 3.13 & $* * *$ \\
\hline$M F^{*} D 3$ & & & & & & & & & & -0.003 & -0.22 & & -0.042 & -1.36 & & 0.003 & 0.21 & \\
\hline SIZE & 0.032 & 0.31 & & -0.108 & -2.00 & $* *$ & 0.140 & 1.10 & & -0.055 & -1.15 & & 0.091 & 1.22 & & -0.100 & -2.02 & $* *$ \\
\hline$B M$ & 0.467 & 1.78 & * & -0.232 & -1.43 & & 0.698 & 2.52 & $* *$ & 0.006 & 0.04 & & 0.325 & 1.34 & & -0.070 & -0.41 & \\
\hline COVERAGE & 0.045 & 0.22 & & 0.216 & 2.37 & $* *$ & -0.171 & -0.68 & & 0.186 & 2.09 & $* *$ & 0.331 & 1.49 & & 0.133 & 1.43 & \\
\hline SPECIAL & -2.088 & -0.99 & & -1.700 & -2.04 & $* *$ & -0.389 & -0.16 & & -1.828 & -1.43 & & -5.909 & -5.05 & $* * *$ & -0.646 & -0.43 & \\
\hline LOSS & -0.337 & -0.87 & & 0.404 & 2.18 & $* *$ & -0.742 & -1.72 & & 0.017 & 0.09 & & -0.047 & -0.15 & & 0.018 & 0.08 & \\
\hline DIFFICULTY & 0.423 & 1.40 & & -0.008 & -0.05 & & 0.430 & 1.37 & & 0.063 & 0.41 & & -0.076 & -0.35 & & 0.135 & 0.71 & \\
\hline $\mathrm{N}$ & 75,927 & & & 78,510 & & & & & & 153,487 & & & 33,281 & & & 120,206 & & \\
\hline Adj. R-sq. & 0.070 & & & 0.012 & & & & & & 0.057 & & & 0.020 & & & 0.077 & & \\
\hline$F R^{*} D 1=F R^{*} D$ & & 2.83 & $* * *$ & & 1.63 & & & & & & 2.60 & $* * *$ & & 1.46 & & & 2.49 & $* *$ \\
\hline$F R^{*} D 2=F R^{*} D$ & & 1.83 & $*$ & & 0.28 & & & & & & 0.00 & & & 0.76 & & & 0.54 & \\
\hline$F R^{*} D 3=F R^{*} D$ & & 7.82 & $* * *$ & & 3.30 & $* * *$ & & & & & 4.99 & $* * *$ & & 2.25 & $* *$ & & 4.44 & $* * *$ \\
\hline
\end{tabular}

This table reports the results of the regression of stock returns on analyst forecast revisions at different points in event time relative to the earnings announcement date and control variables for the propensity-score matched sample. Propensity score is estimated by the following logistic regression for each fiscal quarter: $\operatorname{Pr}(M E F=1)=F\left(\alpha_{0}\right.$ $+\alpha_{1}$ LN_TA $+\alpha_{2}$ BIG4 $+\alpha_{3}$ BETA $+\alpha_{4}$ ABSCHGROA $+\alpha_{5}$ STD_AF $+\alpha_{6}$ EARNINGS_VOLATILITY $+\alpha_{7}$ ASSET_GROWTH $+\alpha_{8}$ LEVERAGE $+\alpha_{9}$ SEGMENTS $+\alpha_{10}$ $R O A+\bar{\alpha}_{11}$ LOSS $+\alpha_{12} H H I+\alpha_{13}$ LITIGATION $+\alpha_{14}$ COVERAGE). All variables are defined in the Appendix. For each fiscal quarter, firms with closest propensity score are matched within caliper width of 0.1 without replacement. We define years between 1996 and 2000 and pre-Reg FD period and between 2001 and 2009 as post-Reg FD period. All test statistics and significance levels are calculated based on standard errors adjusted by a two-dimensional cluster at the analyst and quarter levels. ${ }^{* *}, * *, *$ denote significance at the $1 \%, 5 \%$, and $10 \%$ levels, respectively (two-tailed). 
Table 9

Excluding quiet firms: forecast revision timing and return sensitivity to forecast revisions

\begin{tabular}{|c|c|c|c|c|c|c|c|c|c|c|c|c|c|c|c|c|c|c|}
\hline & \multirow{2}{*}{\multicolumn{3}{|c|}{ With MEF }} & \multirow{2}{*}{\multicolumn{3}{|c|}{ Without MEF }} & \multirow{2}{*}{\multicolumn{3}{|c|}{$\begin{array}{l}\text { Difference between } \\
\text { With and without MEF }\end{array}$}} & \multicolumn{9}{|c|}{$\begin{array}{l}\text { Pooled Sample } \\
\text { after controlling for management forecasts }\end{array}$} \\
\hline & & & & & & & & & & \multicolumn{3}{|c|}{ All revisions } & \multicolumn{3}{|c|}{ Pre-FD } & \multicolumn{3}{|c|}{ Post-FD } \\
\hline & coeff. & t-value & & coeff. & t-value & & difference & t-value & & coeff. & t-value & & coeff. & t-value & & coeff. & t-valu & \\
\hline Intercept & -0.374 & -1.14 & & 0.157 & 0.72 & & -0.532 & -1.46 & & 0.123 & 0.58 & & -0.281 & -0.68 & & 0.220 & 0.90 & \\
\hline$F R * D 1$ & 0.118 & 18.27 & $* * *$ & 0.052 & 15.13 & $* * *$ & 0.066 & 10.90 & $* * *$ & 0.055 & 17.36 & $* * *$ & 0.041 & 9.13 & $* * *$ & 0.060 & 15.41 & $* * *$ \\
\hline$F R * D 2$ & 0.093 & 8.75 & $* * *$ & 0.028 & 4.19 & $* * *$ & 0.066 & 6.25 & $* * *$ & 0.020 & 3.39 & $* * *$ & 0.005 & 0.36 & & 0.025 & 3.87 & $* * *$ \\
\hline$F R^{*} D 3$ & 0.009 & 1.86 & $*$ & 0.016 & 4.70 & $* * *$ & -0.008 & -1.67 & $*$ & 0.015 & 4.73 & $* * *$ & 0.016 & 3.21 & $* * *$ & 0.014 & 3.81 & $* * *$ \\
\hline$M F^{*} D 1$ & & & & & & & & & & 0.139 & 15.22 & $* * *$ & 0.125 & 5.68 & $* * *$ & 0.141 & 14.59 & $* * *$ \\
\hline$M F^{*} D 2$ & & & & & & & & & & 0.303 & 8.96 & $* * *$ & 0.420 & 7.31 & $* * *$ & 0.281 & 7.67 & $* * *$ \\
\hline$M F^{*} D 3$ & & & & & & & & & & -0.006 & -0.65 & & -0.001 & -0.01 & & -0.006 & -0.64 & \\
\hline SIZE & 0.016 & 0.31 & & -0.002 & -0.07 & & 0.018 & 0.32 & & -0.019 & -0.59 & & -0.037 & -0.60 & & -0.014 & -0.39 & \\
\hline$B M$ & 0.536 & 3.30 & $* * *$ & 0.243 & 2.72 & $* * *$ & 0.293 & 1.52 & & 0.283 & 4.00 & $* * *$ & 0.343 & 2.13 & $* *$ & 0.285 & 3.63 & $* * *$ \\
\hline COVERAGE & -0.027 & -0.21 & & -0.089 & -1.55 & & 0.062 & 0.45 & & -0.022 & -0.28 & & 0.198 & 1.49 & & -0.079 & -0.86 & \\
\hline SPECIAL & -0.134 & -0.14 & & -0.544 & -0.86 & & 0.410 & 0.35 & & -0.688 & -1.19 & & -3.945 & -2.66 & $* * *$ & -0.087 & -0.14 & \\
\hline LOSS & -0.018 & -0.08 & & -0.009 & -0.05 & & -0.008 & -0.03 & & -0.041 & -0.31 & & 0.135 & 0.57 & & -0.087 & -0.57 & \\
\hline DIFFICULTY & 0.150 & 0.87 & & 0.049 & 0.54 & & 0.101 & 0.49 & & 0.043 & 0.48 & & 0.086 & 0.55 & & 0.029 & 0.27 & \\
\hline $\mathrm{N}$ & 104,474 & & & 96,537 & & & & & & 199,767 & & & 43,251 & & & 156,516 & & \\
\hline Adj. R-sq. & 0.077 & & & 0.016 & & & & & & 0.076 & & & 0.049 & & & 0.087 & & \\
\hline$F R^{*} D 1=F R^{*} D 2$ & & 2.45 & $* *$ & & 3.72 & $* * *$ & & & & & 6.09 & $* * *$ & & 2.61 & $* * *$ & & 5.86 & $* * *$ \\
\hline$F R * D 2=F R * D 3$ & & 7.63 & $* * *$ & & 1.44 & & & & & & 0.77 & & & 0.82 & & & 1.39 & \\
\hline$F R * D 3=F R * D 1$ & & 16.09 & $* * *$ & & 7.81 & $* * *$ & & & & & 10.10 & $* * *$ & & 4.33 & $* * *$ & & 9.58 & $* * *$ \\
\hline
\end{tabular}

This table reports the results of regression of stock returns on analyst forecast revisions at different points in event time relative to the earnings announcement date and control variables for the sample firms that have earnings forecast at least once during the quarters between $q-3$ and $q$. All variables are defined in the Appendix. We define years between 1996 and 2000 and pre-Reg FD period and between 2001 and 2009 as post-Reg FD period. All test statistics and significance levels are calculated based on standard errors adjusted by a two-dimensional cluster at the analyst and quarter levels. ***,**, * denote significance at the $1 \%$, $5 \%$, and $10 \%$ levels, respectively (two-tailed). 
Table 10

Timing of other information events and return sensitivity to forecast revisions

Panel A: Timing of firm information events

\begin{tabular}{crrr}
\hline & Events excluding Management forecasts & \multicolumn{2}{c}{ Events including Management forecasts } \\
\cline { 2 - 4 } Period & $\mathrm{N}$ & $\%$ & $\mathrm{~N}$ \\
\hline-2 & 2.958 & 14.98 & 10.791 \\
-1 & 283 & 1.43 & 1,034 \\
0 & 4,102 & 20.77 & 23.58 \\
1 & 3,057 & 15.48 & 2.26 \\
2 & 9,349 & 47.34 & 3,250 \\
\hline Total & 19.749 & 100.00 & 7.15 \\
\hline
\end{tabular}

Panel B: Return sensitivity to forecast revisions conditional on events during the quarter after excluding management forecast event observations

\begin{tabular}{|c|c|c|c|c|c|c|c|c|c|c|c|c|}
\hline & \multicolumn{3}{|c|}{ Full Sample } & \multicolumn{3}{|c|}{$\begin{array}{c}\text { With events } \\
\text { (excluding MEF) }\end{array}$} & \multicolumn{3}{|c|}{ Without Events } & \multicolumn{3}{|c|}{$\begin{array}{l}\text { Difference between revisions } \\
\text { with and without Events }\end{array}$} \\
\hline & coeff. & t-value & & coeff. & t-value & & coeff. & t-value & & difference & t-value & \\
\hline Intercept & 0.238 & 1.68 & $*$ & 0.416 & 2.33 & $* *$ & 0.146 & 0.88 & & 0.271 & 1.35 & \\
\hline$F R * D I$ & 0.042 & 15.82 & $* * *$ & 0.051 & 16.00 & $* * *$ & 0.038 & 13.00 & $* * *$ & 0.014 & 4.45 & $* * *$ \\
\hline$F R * D 2$ & 0.020 & 5.00 & $* * *$ & 0.028 & 3.57 & $* * *$ & 0.017 & 3.67 & $* * *$ & 0.011 & 1.26 & $* *$ \\
\hline$F R^{*} D 3$ & 0.017 & 6.66 & $* * *$ & 0.021 & 5.65 & $* * *$ & 0.014 & 4.25 & $* * *$ & 0.007 & 1.49 & \\
\hline$S I Z E$ & -0.014 & -0.73 & & -0.018 & -0.63 & & -0.014 & -0.64 & & -0.004 & -0.14 & \\
\hline$B M$ & 0.092 & 1.39 & & 0.209 & 1.66 & $*$ & 0.033 & 0.49 & & 0.177 & 1.38 & $*$ \\
\hline COVERAGE & -0.049 & -1.03 & & -0.152 & -2.30 & $* *$ & 0.001 & 0.02 & & -0.153 & -2.06 & $* *$ \\
\hline SPECIAL & -0.134 & -0.32 & & -0.528 & -0.65 & & 0.034 & 0.06 & & -0.562 & -0.55 & \\
\hline LOSS & -0.168 & -1.55 & & -0.428 & -2.85 & $* * *$ & -0.035 & -0.31 & & -0.393 & -2.80 & \\
\hline DIFFICULTY & 0.142 & 2.99 & $* * *$ & 0.217 & 2.91 & $* * *$ & 0.107 & 1.97 & $* *$ & 0.111 & 1.32 & $* *$ \\
\hline $\mathrm{N}$ & 273,137 & & & 84,233 & & & 188,904 & & & & & \\
\hline Adj. R-sq. & 0.012 & & & 0.016 & & & 0.010 & & & & & \\
\hline$F R * D 1=F R * D$ & & 4.99 & $* * *$ & & 3.12 & $* * *$ & & 3.87 & $* * *$ & & & \\
\hline$F R * D 2=F R * D$ & & 0.58 & & & 0.70 & & & 0.53 & & & & \\
\hline$F R * D 3=F R * D$ & & 7.18 & $* * *$ & & 7.20 & $* * *$ & & 5.31 & $* * *$ & & & \\
\hline
\end{tabular}


Panel C: Return sensitivity to forecast revisions conditional on events during the quarter including management forecast (MEF)

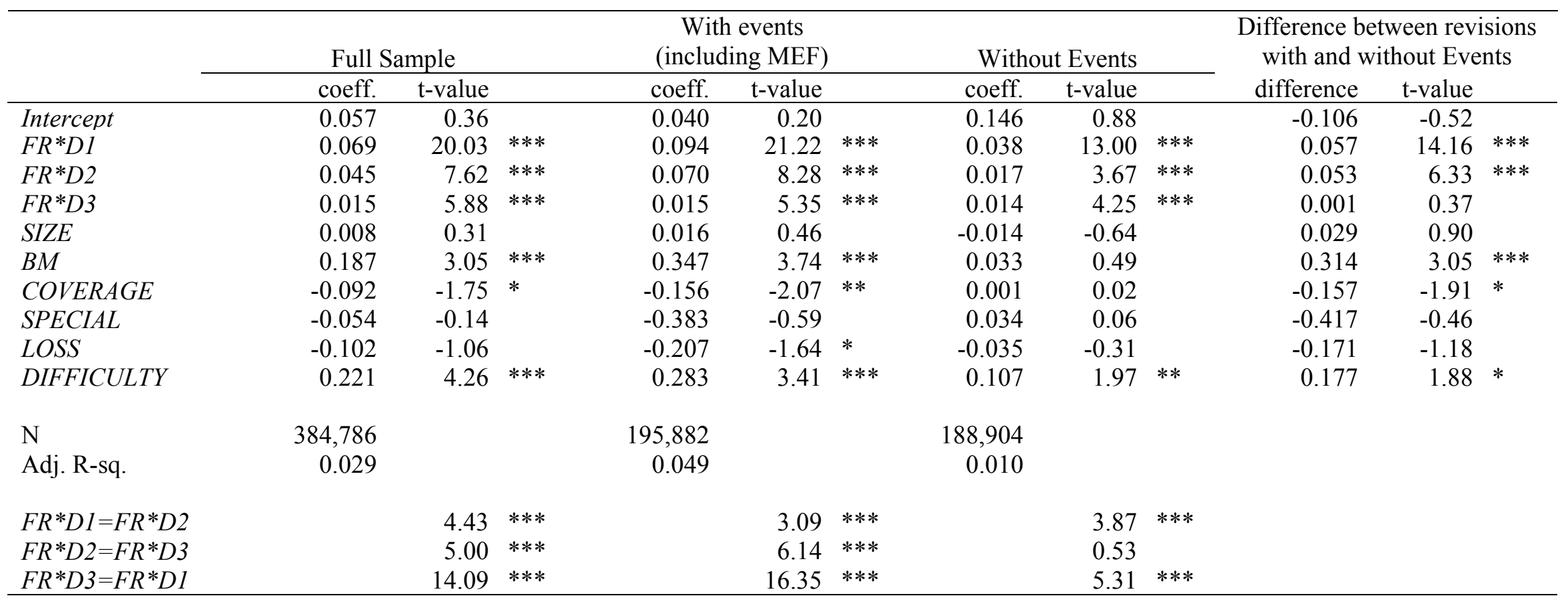

This table reports the results of regression of stock returns on analyst forecast revisions and firm informational events at different points in event time relative to the earnings announcement and control variables. All variables are defined in the Appendix. Firm informational events include debt and equity issues, multiple analyst recommendations, merger and acquisition, and dividend declaration. In Panel B and C, all test statistics and significance levels are calculated based on standard errors adjusted by a twodimensional cluster at the analyst and quarter levels. $* * *, * *, *$ denote significance at the $1 \%, 5 \%$, and $10 \%$ levels, respectively (two-tailed). 